\title{
A data de nascimento de Afonso I
}

\section{Abel Estefânio}

\section{OpenEdition}

\section{Journals}

\section{Edição electrónica}

URL: http://journals.openedition.org/medievalista/465

DOI: 10.4000/medievalista.465

ISSN: 1646-740X

\section{Editora}

Instituto de Estudos Medievais - FCSH-UNL

\section{Refêrencia eletrónica}

Abel Estefânio, «A data de nascimento de Afonso | », Medievalista [Online], 8 | 2010, posto online no dia 01 dezembro 2010, consultado no dia 30 abril 2019. URL : http://journals.openedition.org/ medievalista/465 ; DOI : 10.4000/medievalista.465 


\section{Titulo: A data de nascimento de Afonso I}

Autor(es): Abel Estefânio

Enquadramento Institucional:

Contacto: aestefanio@hotmail.com

Fonte: Medievalista [Em linha]. №8, (Julho 2010). Direc. José Mattoso. Lisboa: IEM.

Disponível em: http://www2.fcsh.unl.pt/iem/medievalista/

ISSN: 1646-740X

\section{Resumo}

Apesar do desafio aliciante que sempre constitui um enigma, a contradição das fontes mais antigas sobre a data de nascimento de Afonso Henriques nunca foi devidamente estudada, por não se considerar o assunto suficientemente relevante para a história, pouco interessada com a averiguação isolada de factos do passado. Não é de estranhar, assim, que este artigo surja à margem da historiografia profissional, apesar de ter sido a recente publicação da biografia de D. Afonso Henriques que veio renovar o interesse pelo facto. Este trabalho propõe-se revisitar as fontes coevas à luz da crítica textual. Pretende-se demonstrar que a Vita Theotonii, sendo a fonte primordial, contém já em si os vestígios do «pecado original» donde procede a confusão acerca da data de nascimento do nosso primeiro rei, que perdurou até aos nossos dias. A finalidade explicitada acaba assim por se tornar um pretexto para uma reflexão mais ampla sobre os problemas da transmissão textual.

\section{Abstract}

Despite the challenge that is always an enigma, the contradiction between the sources of the date of birth of Afonso Henriques had never been properly studied because it is not considered a matter of history, little concerned with the investigation of isolated facts from the past. No wonder that this article arise in 
the margins of professional historiography, despite having been the recent publication of the biography of D. Afonso Henriques, who came to renew the interest in the subject. The aim of this paper is to revisit the coeval sources in light of the problem. We intend to show that "Vita Theotonii" is not only the primary source but also contains within itself the «original sin» upon which was settled the confusion over the date of birth of our first king, which lasted until the present. The explicit purpose eventually had become a plea for a broader discussion of the problems of textual transmission.

\section{A data de nascimento de Afonso I}

Abel Estefânio

«Siquidem mortuo patre suo Comite Domino Henrico cum adhuc ipse puer esset duorum aut trium annorum» (Chronica Gothorum) «Pois ao tempo que seu pay o cõde dom Anrrique faleceo, elle principe dõ Afonso ficou em idade de seys annos» (Ásia de João de Barros)

\section{Introdução e enquadramento do estudo}

No ano em que as cidades de Viseu, Guimarães e Coimbra comemoraram os 900 anos do nascimento de D. Afonso Henriques, podemos constatar a importância que estas três cidades colocaram na reivindicação do fundador da nacionalidade. O confronto entre elas lembra o de várias mães disputando a mesma criança. À alegria da primeira em acolher o filho que não sabia que tinha, responde a segunda, dramatizando a perda de 
um filho que sempre considerou seu, e a terceira, resignada com a partilha do filho com as outras duas. Perante estas exacerbadas paixões, o Presidente da Republica demarcouse, com evidente sensatez: «Às dúvidas dos historiadores, respondemos, e basta: viu a primeira luz em terra que tornou Portugal e, afortunadamente, nasceu quando foi necessário» ${ }^{1}$.

Curiosamente, apesar de todas as polémicas, as comemorações dos 900 anos sobre o nascimento do primeiro rei português coincidiram quanto ao ano da sua realização. A mesma data serviu ainda de pretexto para a realização do colóquio internacional "Afonso Henriques: em torno da criação e consolidação das monarquias do Ocidente Europeu (séculos XII-XIII), Identidades e liminaridades", realizado na Faculdade de Letras da Universidade de Lisboa, de 14 a 16 de Dezembro. Na conferência de abertura, o Prof. José Mattoso começou por informar que tinha voltado à história para escrever a biografia de D. Afonso Henriques, pelo dever moral de preencher o lugar vazio deixado pelo Prof. Luís Krus, e que aproveitava a oportunidade para esclarecer a sua posição acerca da data de nascimento de D. Afonso Henriques ${ }^{2}$. Referiu a tradição do nascimento em Guimarães, passando pela posição de Torquato de Sousa Soares, que propôs Coimbra, até à de Almeida Fernandes, em Viseu, Agosto de 1109. Continuou afirmando que a demonstração deste lhe pareceu credível, mas que não fez investigação sobre o assunto. Considerou, contudo, que A. Fernandes preocupou-se pouco com a data $^{3}$. A hipótese de Viseu dependia assim do ano, dada a contradição das fontes. Só haveria certeza se D. Teresa tivesse permanecido sempre em Viseu, entre 1106 e 1110. O Prof. José Mattoso, lamentando não o ter dito anteriormente com clareza suficiente, afirmou peremptoriamente: «Não considero encerrado o problema da data e local».

Os problemas em história devem ser definidos pela ordem cronológica dos testemunhos a interpretar como fontes do conhecimento do passado. Este trabalho analisa o problema da determinação da data de nascimento de Afonso Henriques, a partir das fontes coevas. Mas será possível explicar informações divergentes entre fontes igualmente credíveis?

\footnotetext{
${ }^{1}$ Discurso na sessão solene comemorativa dos 900 anos de nascimento do rei D. Afonso Henriques, realizada em Guimarães, no dia 24 de Junho de 2009, em linha, disponível em http://www.presidencia.pt/?idc=21\&idi=29496\&action=7, consultado em 31.01.2010.

${ }^{2}$ J. Mattoso, 2009. Texto enviado amavelmente pelo autor.

${ }^{3} \mathrm{Na}$ verdade, A. Fernandes $(2007$, p. 161) tomou o ano como pressuposto da tese do nascimento em Viseu, como explicitamente o admitiu: «Uma única circunstância poderia abalar seriamente o edifício construído - obrigar a pô-lo de lado: provar-se que D. Afonso Henriques não nasceu em 1109».
} 
Estamos conscientes que este é um processo complexo e, à partida, de eficácia duvidosa. Se o conseguirmos, estaremos no bom caminho para se encontrar a data de nascimento de Afonso Henriques. Caso contrário, podemos estar perante um problema insolúvel. Optei por seguir um processo iterativo, procurando ajustar cada item de informação à seguinte como se tratasse de um cubo de Rubik. Como no famoso quebra-cabeças tridimensional, a construção não seguiu um processo linear, sendo necessário refazer as «faces» do problema várias vezes, até chegar a uma combinação que me pareceu adequada. Procurei justificar cada «movimento», cada conjugação diferente que fui fazendo, em «autoridades», como dou conta na bibliografia consultada, mas também escrevendo aos autores, tendo obtido um número muito significativo de contribuições directas, numa manifestação de abertura que me surpreendeu positivamente, encorajando-me a prosseguir com o trabalho. A todos eles agradeço a colaboração.

Queria mencionar especialmente o Senhor Professor José Mattoso pela sua disponibilidade, pelos seus ensinamentos e pela sua orientação nesta minha incursão pela «sua» floresta medieval, para a qual não estava preparado. Perdoe-me o historiador insigne por escrever agradecidamente o seu nome neste tosco trabalho, composto até na mesma linguagem dos velhos cronicões.

Como é evidente, as conclusões apresentadas são da minha inteira responsabilidade e os pressupostos em que me baseei, em alguns casos, não são unanimemente aceites. Em algumas questões de pormenor, poucas, em que manifesto a minha discordância, procuro fundamentar as razões subjacentes. Embora me pareça que os resultados obtidos reforçam os pressupostos de que parti, não deixam de depender deles, nomeadamente no que respeita à datação crítica das fontes. Com outros pressupostos, as conclusões poderiam ser diferentes.

Na falta de fontes diplomáticas que nos informem sobre o assunto, a questão só pode ser examinada à luz da crítica textual das fontes analísticas e dos textos narrativos ${ }^{4}$. $\mathrm{O}$

\footnotetext{
${ }^{4}$ Em 1980, J. Mattoso, nas notas críticas à História de Portugal de Alexandre Herculano (1989, tomo I, p. 389 , no 41 e p. 689, XI), considerou que para a resolução do problema da determinação da data de nascimento de Afonso Henriques se devia levar em conta as conclusões de Pierre David acerca dos Annales Portucalenses veteres, as de Monica Blöcker-Walter sobre os Annales D. Alfonsi Portugalensius regis e as de Lindley Cintra sobre as fontes literárias redigidas em Santa Cruz de Coimbra, que dispomos agora em boas edições do Prof. Aires do Nascimento.
} 
trabalho que apresento divide-se em duas partes. A primeira é dedicada ao estudo da Vita Theotonii, escrita cerca de 1162, que creio ser a fonte mais antiga a fazer referência à data de nascimento de Afonso Henriques. Na segunda parte, são examinadas as duas tradições que a partir dessa mesma fonte surgiram relativamente ao mesmo facto. A primeira tradição é representada pela Translatio et Miracula S. Vincentii, pelo Indiculum Fundationis Monasterii Beati Vincentii Vlixbone, escritos ainda no século XII, e pelo texto perdido de um martirológio da Sé de Lisboa. A segunda encontra-se representada pelo De expugnatione Scallabis e pelos Annales D. Alfonsi Portugalensius regis, ambos escritos por volta de 1185, e ainda por dois testemunhos dos Annales Portucalenses veteres de 1168 (perdido): o Livro de Noa I e os Anais Lamecenses. Serão sempre transcritas as fontes nas partes que considero essenciais, submetendo-as a um trabalho de crítica textual. Finalmente, fazendo uso de um stemma da transmissão das várias tradições, apresentaremos uma síntese das conclusões deste trabalho.

\section{A Vita Theotonii}

O único manuscrito latino da Vita Beatissimi Domni Theotonii primi prioris monasterii sanctae crucis colimbriensis é um texto da segunda metade do século XII, com o $\mathrm{n}^{\circ} 29$ da velha catalogação dos manuscritos provenientes do Mosteiro de Santa Cruz, que se encontra na Biblioteca Pública Municipal do Porto, onde tem o $\mathrm{n}^{\mathrm{o}}$ geral $52^{5}$. De autor anónimo, mas discípulo do biografado, exprime a saudade causada pela morte do primeiro prior de Santa Cruz. A não referência à canonização do santo, e o facto de não mencionar quaisquer acontecimentos miraculosos ocorridos depois da morte do primeiro Prior de Santa Cruz, são argumentos que levam o Prof. Aires Nascimento a supor que esta hagiografia possa ter sido redigida no período compreendido entre a data em que morreu e a data em que foi canonizado, que teria ocorrido no primeiro aniversário da morte do prior. Esta é uma das razões para dedicarmos especial atenção às datas da morte e da canonização de São Teotónio. A outra é, como veremos, a relação que se estabelece no texto, entre a data da morte do nosso primeiro santo e a data de nascimento do primeiro rei. Antes, porém, de examinar o passo que nos interessa, convém averiguar os usos do cômputo adoptados no scriptorium de Santa Cruz.

\footnotetext{
${ }^{5}$ Vita Theotonii, Ms. Santa Cruz no 29/52, cf. CCL, 1997, pp. 158-164.
} 
D. Teotónio nasceu no Alto-Minho, no lugar de Ganfei. No início da adolescência foi levado para Coimbra pelo seu tio materno, D. Crestónio, bispo de Tui, quando este foi transferido para a diocese de Coimbra (1092-1098). Frequentou a escola capitular, sob a orientação de D. Telo, arcediago da mesma Sé. Depois da morte do tio seria nomeado administrador da Diocese de Viseu, então confiada à administração da Diocese de Coimbra. Em Viseu, Teotónio vem a ocupar o lugar de prior por insistência do bispo D. Gonçalo (1109-1128). Por volta de 1121, abandona o cargo para fazer uma peregrinação a Jerusalém ${ }^{6}$. Faria ainda uma segunda peregrinação, antes de ser convidado por D. Telo para fundar a nova comunidade de Cónegos Regrantes de Santo Agostinho, tendo sido nomeado primeiro prior do Mosteiro de Santa Cruz de Coimbra.

\subsection{Os usos cronológicos de Santa Cruz e a data de fundação do Mosteiro}

\subsubsection{Na Vita Tellonis}

D. Telo é o fundador do Mosteiro de Cónegos Regrantes de Santa Cruz de Coimbra. O acto fundacional vem descrito na Vita Tellonis, escrita talvez antes de 1155. Embora não seja uma fonte directa no âmbito do nosso estudo, ela é importante para o conhecimento dos usos cronológicos adoptados pelos cónegos e consequentemente para a interpretação das datas contidas na Vita Theotonii, como veremos adiante. O primeiro problema coloca-se a respeito do uso da «indicção»e do «estilo» relativo ao começo do ano.

Na Vita Tellonis refere-se que:

«no ano de 1131 da Incarnação do Senhor, oitava indicção (...), o arcediago Telo, agregando a si uma falange de homens de primeiro plano em número igual ao dos doze Apóstolos, começou a lançar os fundamentos do mosteiro de Santa Cruz nos arrabaldes de Coimbra» ${ }^{7}$.

Recorde-se que no estilo da Encarnação ou da Anunciação o ano começava a 25 de Março, mas há uma diferença de um ano entre a contagem segundo o cômputo de Pisa e o de Florença ${ }^{8}$. Tomando o ano da encarnação de 1131, este, segundo o cômputo de

\footnotetext{
${ }^{6}$ Sobre as peregrinações de São Teotónio, consultar J. Marques, 2001, $2^{\circ}$ vol., p. 113.

${ }^{7}$ Vita Tellonis, ed. A. Nascimento, 1998, pp. 55 e 57.

${ }^{8}$ A. Costa, 1993, pp. 22-23.
} 
Pisa, começaria a 25 de Março de 1130, enquanto pelo cômputo de Florença começaria a 25 de Março de 1131. Qual dos dois cômputos é que devemos considerar? A pista deixada no próprio texto, relativa a esta questão, é-nos dada pela indicção. Recorde-se que a indicção era um período de 15 anos usado em Roma para marcar a cobrança dum imposto e mais tarde empregado nas Bulas Pontifícias, mas que apresenta a dificuldade de haver variantes quanto ao começo da sua contagem ${ }^{9}$. Note-se que a bula Desiderium quod de 26 de Maio do ano da encarnação de 1135 refere a $12^{\mathrm{a}}$ indicção $^{10}$. A sua contagem é consistente com a indicção grega, com o seu ponto de partida a 1 de Setembro do ano 313 d. C., que mereceu a preferência dos papas do ano de 584 a $1147^{11}$. Os quatros anos que separam a data da fundação do mosteiro da data da bula têm correspondência nas quatro indicções que separam as duas datas. Deste modo, a bula é, com toda a certeza, uma das fontes históricas consultadas pelo organizador e redactor da Vita Tellonis. Como a Chancelaria pontifícia adoptou o ano da encarnação segundo o cômputo de Florença $^{12}$, e a sua utilização é a regra que foi utilizada normalmente, quer nos diplomas medievais portugueses, quer no panorama epigráfico ${ }^{13}$, somos levados a admitir que teria sido também esse o critério usado na Vita Tellonis. $\mathrm{O}$ mesmo texto informa-nos que «lançaram, pois, a primeira pedra de fundação no dia 28 de Junho, vigília dos príncipes dos Apóstolos Pedro e Paulo» ${ }^{14}$, donde se deduz que a data de fundação do Mosteiro de Santa Cruz é o dia 28 de Junho de 1131. Conforme nos mostra um documento datado do dia seguinte, D. Telo fez nessa altura a doação dos banhos régios, que tinha recebido de D. Afonso Henriques em Dezembro do ano anterior, ao Mosteiro de Santa Cruz, onde se ergueria a igreja conventual ${ }^{15}$.

\footnotetext{
${ }^{9}$ A. Nascimento, 1998, p. 127, no 3 . O mesmo assunto encontra-se desenvolvido por S. Gomes, 2007, pp. 105-119.

${ }^{10}$ A bula Desiderium quod está contida na Vita Tellonis (ed. A. Nascimento, 1998, pp.64-67).

${ }^{11}$ A. Cappelli, 2002, prefácio, $n^{\circ} 4$ e p. 5.

12 A. Costa, 1993, p. 24.

${ }^{13}$ Cf. M. Barroca, 2000, vol. 1, pp. 222-223.

${ }^{14}$ Vita Tellonis, ed. A. Nascimento, 1998, p. 63.

${ }^{15}$ DMP-DR, vol. 1, tomo 1, p. 138, doc. 115, de 9 de Dezembro de 1130, e Livro Santo de Santa Cruz, ed. L. Ventura e A. Santiago, 1990, nº 6, de 29 de Junho de 1131, p. 117.
} 


\subsubsection{Na Vita Theotonii}

Por sua vez, na Vita Theotonii refere-se que «Na era de 1170, pois, ou seja no ano da Incarnação do Filho de Deus de 1132 , se reuniram em vida de comunidade» ${ }^{16}$. Seguem-se duas datas que também se encontram na Vita Tellonis: a data de inicio da construção do mosteiro a 28 de Junho, já referida, e a de 24 de Fevereiro do ano seguinte, em que se inicia a vida canónica ${ }^{17}$. A expressão latina original desta última data «Sexto autem kalendas Martii sequentis in capite ieiunii» merece a nossa atenção não só pela referência ao jejum quaresmal que se iniciaria na quarta-feira de cinzas ${ }^{18}$, mas também por não ser clara relativamente ao problema da contagem das calendas nos anos bissextos ${ }^{19}$. Rigorosamente, o autor deveria ter escrito «bis VI. ${ }^{\circ}$ Kalendas Martii», de forma a registar inequivocamente o dia 24 de Fevereiro ${ }^{20}$. Note-se que este dia vem assinalado na Vita Tellonis no ano da encarnação de 1131, segundo o cômputo florentino (que termina a 24 de Março de 1132 e tem a indicção 5), ou seja, a 24 de Fevereiro de 1132. Por sua vez, como a Vita Theotonii assinala o mesmo dia no ano da encarnação de 1132, parece que o cálculo foi feito pelo cômputo de Pisa. Só nesta situação é que o dia 24 de Fevereiro corresponde ao ano do nascimento de 1132, perfazendo os 38 anos de diferença relativamente à Era Hispânica. Poderia ser um caso raro da utilização entre nós do cômputo pisano, dado que só assim é que a informação que veicula é compatível com a da Vita Tellonis. De facto esta fonte devia ser bem conhecida do seu autor, pois é por ele explicitamente nomeada como se depreende do parágrafo seguinte: «Se alguém, aliás, quiser saber mais pormenores sobre a localização do sítio e dos privilégios do Mosteiro, leia a obra do Mestre Dom Pedro Alfarde $\gg^{21}$. Mas, com esta relação de dependência claramente estabelecida, e a sua

\footnotetext{
${ }^{16}$ Vita Theotonii, ed. A. Nascimento, 1998, pp. 166-167: «Igitur sub era M. ${ }^{\text {a }}$ C. ${ }^{\text {a }}$ LXX. ${ }^{\text {a }}$ uel incarnatione filii Dei anno M. ${ }^{\circ}\left[\mathrm{C}^{\mathrm{o}}\right] \mathrm{XXX}^{\circ} \mathrm{II}^{\circ}$, in unum conuenerunt (...)». O segundo número - $\mathrm{C}$ - sem o qual não haveria equivalência à Era, aparece sobrelinhado no manuscrito, provavelmente por intervenção no século XV.

${ }^{17}$ Frei Timóteo dos Mártires, 1955, pp. 16-17, considera que a cerimónia em que receberam o hábito canónico decorreu na manhã do dia 24 de Fevereiro de 1132 e que da parte da tarde do mesmo dia D. Teotónio foi eleito como prior por unanimidade por proposta de D. Telo.

${ }^{18}$ Vita Theotonii, ed. A. Nascimento, 1998, p. 166 e A. Cappeli, 1998, p. 74, com a Páscoa a 10 de Abril.

${ }^{19}$ Como o ano de 1132 foi bissexto, a véspera (pridie) das calendas de Março é a 29 de Fevereiro e o sexto dia das calendas de Março que ocorre a 25 de Fevereiro, repete-se no dia 24. Do dia 23 de Fevereiro (sétimo das calendas) para trás, contam-se as calendas como nos anos comuns.

${ }^{20}$ Cf. A. Nascimento, 1998, p. 218, n⿳ 56. A imprecisão terá induzido A. Martins (2003, p. 166) a considerar que se tratava do dia 25 de Fevereiro.

${ }^{21}$ Vita Theotonii, ed. A. Nascimento, 1998, p. 167.
} 
produção separada no tempo por apenas sete anos, pareceu-me estranho que houvesse mudança do cômputo de Florença para o de Pisa.

Com o objectivo de obter novos indícios que me ajudassem a resolver esta dúvida, fui à Biblioteca Pública Municipal do Porto consultar o manuscrito da Vita Theotonii. No sentido de assegurar a sua preservação, o documento não está normalmente disponível aos leitores. Em sua substituição é disponibilizado em microfilme. $\mathrm{O}$ acaso levou a que, no período em que conduzi a presente investigação, a sala onde estava o equipamento de leitura de microfilme não se encontrava disponível, devido a obras, pelo que me foi permitido consultar o nosso «bom manuscript» de finais do século XII. O facto de o pergaminho estar raspado precisamente no sítio onde está a data da Era Hispânica e no último dígito do correspondente ano da encarnação ${ }^{22}$, conforme se vê nas manchas da fig. 1, dão-nos um precioso indício sobre os problemas de cronologia enfrentados pelo autor ou pelo copista.

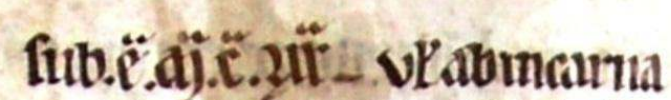

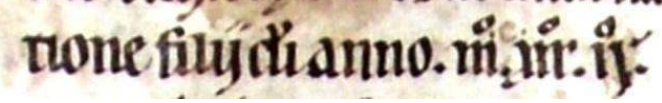

... sub era M. ${ }^{a}$ C. ${ }^{a}$ LXX. ${ }^{a}$ uel ab incarna tione filii dei anno M. ${ }^{\circ}\left[\mathrm{C}^{\circ}\right]$ XXX..$^{\circ}$ II. $^{\circ}{ }^{23}$

fig. 1 - Pormenor da Vita Theotonii, Ms. Santa Cruz, 29, fl. 9v.

(Biblioteca Pública Municipal do Porto)

$\mathrm{Na}$ ausência de uma análise técnica especializada, atendendo apenas à posição das manchas e ao facto de ter ficado um espaço livre a seguir à primeira data, avançamos com a hipótese de ter havido alteração ou equívoco neste ponto do texto: a primeira data seria, inicialmente, $\left\langle M{ }^{a}{ }^{a}\right.$ C. ${ }^{a}$ LXVIIII. ${ }^{a} »$, e teria sido alterada por raspagem do VIIII, substituído por um X; na segunda, seria, em sequência, acrescentada de uma unidade. Sendo assim, o original teria seguido o cômputo de Florença, em perfeita consonância com a Vita Tellonis. A alteração parece ter sido efectuada pela mesma mão.

\footnotetext{
22 Indícios estes que se juntam assim à anteriormente referida ausência do segundo dígito do ano da encarnação.

${ }^{23}$ Ibid., p. 166.
} 


\subsection{Sobre a data em que São Teotónio morreu}

Ao longo da sua vida, São Teotónio desempenhou o papel de colaborador espiritual de D. Afonso Henriques $^{24}$. Diz a sua biografia que o Rei, quando soube da sua morte, teria dito: «antes estará a sua alma no céu do que o corpo no sepulcro» ${ }^{25}$. A data da morte de São Teotónio em 18 de Fevereiro de 1162 merece actualmente o consenso generalizado de todos os historiadores ${ }^{26}$. Poderá assim parecer ocioso determo-nos na análise dos elementos de prova. Penso, contudo, que merece a pena fazer esse percurso, pois, embora o último documento de que dispomos do prior Teotónio seja de $1162^{27}$, isso, só por si, não nos permite concluir com segurança que não tenha vivido para além dessa data.

A informação associada à data em que São Teotónio morreu, que consta do último parágrafo do texto da Vita Theotonii, apresentado na fig. 2, vai ser o nosso ponto de partida para a construção de uma hipótese que explique a divergência das fontes acerca do ano de nascimento do rei.

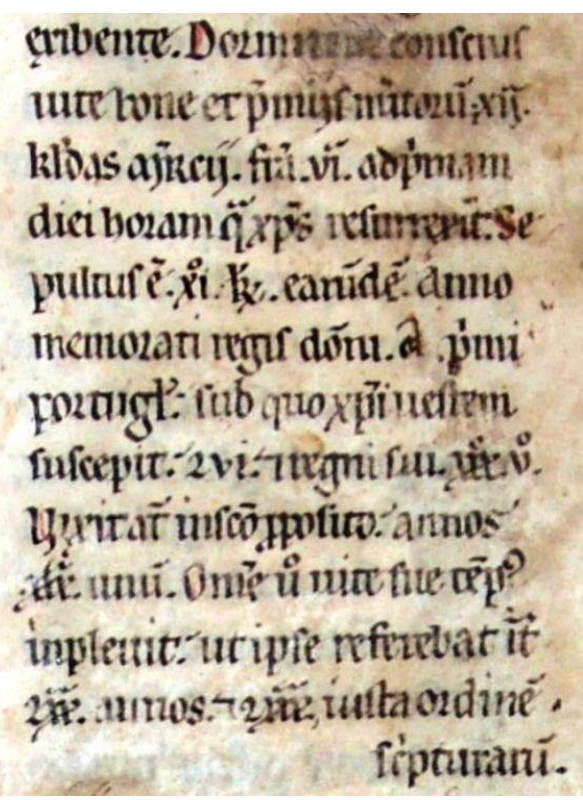

... Dormiuit conscius uite bone et premiis meritorum XII.m Kalendas Marcii, feria $\mathrm{VI}^{\mathrm{a}}$, ad primam diei horam qua Christus resurrexit. Se pultus est $\mathrm{XI}^{\circ}$ Kal. earundem anno memorati regis domni A[lfonsi] primi Portug[a]lis, sub quo Christi uestem suscepit, $\mathrm{LVI}^{\circ}$, et regni sui $\mathrm{XXX}^{\mathrm{o}} \mathrm{V}^{\mathrm{o}}$. Vixit autem in sancto proposito annos $\mathrm{XXX}^{\mathrm{a}}$ unum. Omne uero uite sue tempus inpleuit, ut ipse referebat inter $\mathrm{LXX}^{\mathrm{a}}$ annos et $\mathrm{LXXX}^{\mathrm{a}}$ iusta ordinem Scripturarum. ${ }^{28}$

fig. 2 - Pormenor da Vita Theotonii, Ms. Santa Cruz, 29, fl. 19v.

(Biblioteca Pública Municipal do Porto)

\footnotetext{
${ }^{24}$ Cf. J. Mattoso, 2007, pp. 179-182.

${ }^{25}$ Vita Theotonii, ed. A. Nascimento, 1998, p. 199.

${ }^{26} \mathrm{O}$ ano não está explicito no texto, mas pode deduzir-se dos elementos cronológicos que apresenta. Apenas se encontra uma ténue anotação no final do manuscrito, possivelmente pela mesma mão que numerou os parágrafos (séc. XV?), onde se lê: «Faleceu na era 1200 segundo o letreiro do santo na sepultura».

${ }^{27}$ Cf. S. Gomes, p. 736: Intitulationes de D. Teotónio: 1134-1162.

${ }^{28}$ Vita Theotonii, ed. A. Nascimento, 1998, p. 200.
} 


\subsubsection{O lapsus calami do dia da semana}

O facto de a pontuação de todo o parágrafo estar reforçada a vermelho na primeira letra de cada frase, situação que é excepcional no texto, permite-nos intuir o cuidado envolvido na compilação dos elementos cronológicos aí expressos. Apesar disso, encontramos um problema associado ao dia da morte de São Teotónio. Para a sua análise detalhada, começamos por tomar a primeira frase dessa cronologia que o Prof. Aires Nascimento verteu para português do seguinte modo ${ }^{29}$ :

«Adormeceu na consciência de ter vivido bem e dos prémios dos méritos, no dia décimo segundo antes das calendas de Março, a um sábado, à primeira hora do dia, aquela em que Cristo ressuscitou.».

Conforme se vê, onde no texto original estava «feria VI» (sexta-feira), o Prof. A. Nascimento considerou dever tratar-se de «feria VI[I]» (sábado) ${ }^{30}$. A correcção proposta resulta de o dia da semana indicado no texto do manuscrito não corresponder ao dia do mês desse ano. Com efeito, segundo as tabelas de Cappelli, diz A. Nascimento, aquele dia recaiu num sábado. Trata-se, porém de um equívoco: as tabelas mostram que esse dia foi um domingo ${ }^{31}$. O dia XII das kalendas de Março, 18 de Fevereiro, seria, de facto, um sábado se o ano fosse bissexto. Todavia 1162 foi um ano comum. A. Nascimento deve ter confundido as colunas da tabela, tomando a dos anos bissextos pela dos anos comuns. Fê-lo na convicção de que resolveria assim uma contradição aparente do texto, pois que no fólio $19^{\text {ra }}$ assinala-se que Teotónio é surpreendido pela morte:

«Cum nos septima sabbatti post matutinos seniorum copiosius benediceret, repente super humerum caput paululum inclinauit».

A «septima sabbati» viria confirmar a datação da morte num sábado (feria VII), como sétimo dia, o dia do descanso divino, e acha menos plausível a manutenção da

\footnotetext{
${ }^{29}$ Ibid., p. 201.

${ }^{30}$ A. Nascimento, 1998, p. 222, no 90.

${ }^{31}$ Cf. A. Cappelli, 1998, p. 70, em correlação com a Páscoa, que em 1162 ocorreu a 8 de Abril.
} 
designação dos dias da semana por um esquema directamente numérico ${ }^{32}$. Com efeito, parece que, ao considerarmos que 18 de Fevereiro de 1162 foi um domingo, teríamos de assinalar uma contradição com a expressão «septima sabbati». Penso, todavia, que esta expressão se limita a associar a morte de Teotónio ao dia do descanso divino do calendário judaico. Entendo assim que não se pretendeu nomear o dia da semana, pois nesse caso, certamente seria usado o nome do calendário do Papa Silvestre «sabbatum» ${ }^{33}$ em vez do hebraico «septima sabbati» ${ }^{34}$. Como seria de esperar, no que se refere à forma de indicar uma sexta-feira no texto, verificamos haver uniformidade de critério $^{35}$.

Existe ainda um outro aspecto na mesma citação que merece a nossa atenção. O Prof. A. Nascimento substituiu na frase acima citada «seniorum» por «mortuorum» pensando tratar-se de um momento das matinas ${ }^{36}$. Sobre este aspecto específico, a tradução quatrocentista da Vida de S. Teotónio com o título de "Vida do bem aventurado Padre S. Teotónio primeiro prior que foi no mosteiro de Santa Cruz" apresenta um alternativa que merece a pena referir ${ }^{37}$ :

«hũa sesta feira, depois de matinas, inclinou depressa hũ pouco a cabeça sobre hũ ombro, de hũ dos velhos, e mais copiosamente lancaua a bençã̃»

Tomando a tradução de «seniorum» por «velhos» ${ }^{38}$ e a nossa interpretação sobre a natureza figurativa de «septima sabbati» como «dia do descanso divino», estamos em condições de propor uma nova tradução para a frase como um todo:

\footnotetext{
${ }^{32}$ A. Nascimento, 1998 , p. $221, \mathrm{n}^{\circ} 84$.

${ }^{33}$ Quando, no fólio $4^{\text {ra }}$ da Vita Theotonii, o autor antigo efectivamente pretendeu nomear o sábado, usou «sabbatorum».

${ }^{34}$ Sobre os calendários do Papa Silvestre e Hebraico, ver M. Boléo, [1941] e G. Rausing, 1995, pp. 229238.

${ }^{35}$ Vita Theotonii, ed. A. Nascimento, 1998, p. 150, fólio $4^{\mathrm{va}}$ : «In omniquoque feria $\mathrm{VI}^{\mathrm{a}}{ }$.

${ }^{36}$ Ibid., pp. 199 e 221, n $^{\circ} 86$.

${ }^{37}$ Ibid., p. 315 e BPMP, códice 414, publ. in CMA, 1968, p. 172.

${ }^{38}$ Coerente com a utilização de «senioribus» no mesmo texto, que é traduzido por «antigos», na edição quatrocentista, e por «anciãos» na edição de A. Nascimento (1998, p. 288, no 1 , fl. $1^{\text {va }}$ e pp. 140-141, respectivamente).
} 
«Como no dia do descanso divino, e depois de nos ter dado a bênção mais profusamente, de repente, inclinou a sua cabeça um tanto sobre o ombro de um ancião.»

A análise do problema do dia da semana fica assim restringida apenas ao último parágrafo da Vita Theotonii. É oportuno referir que existe um número considerável de desvios de um grau na ordem da féria em documentos medievais, podendo ter origem no autor ou no copista ${ }^{39}$. No caso em análise - 18 de Fevereiro de 1162 - o dia da semana assinalado (sexta-feira), estaria dois graus afastado do dia em que efectivamente ocorreu (um domingo). Seria mais remota a possibilidade de o autor anónimo ter errado em um grau, por defeito, fixando um sábado onde era um domingo, e um copista, cumulativamente, ler no original «feria VII» e escrever «feria VI».

Podemos fazer o exercício de verificar em que ano próximo de 1162 é que se encontra uma sexta-feira a 18 de Fevereiro. Por consulta das tabelas do Cappeli verificamos que o ano mais próximo do de 1162 em que isso acontece, é o ano de $1166^{40}$. Foi, talvez por esta razão que D. Joaquim da Encarnação, cónego regrante de Santa Cruz na segunda metade do séc. XVIII, tal como o já fizera o autor dos "Acta Sanctorum"41, considerou ser este o ano em que morreu o nosso primeiro santo ${ }^{42}$. Isto apesar de ainda ter visto o «letreiro porém, que se pôz na sepultura do sancto, no Capitulo, se diz ser sua morte na era de 1200, que vem a ser anno de 1162, e é o que seguem os nossos Historiadores ordinariamente» ${ }^{43}$. A posição de J. Encarnação é muito interessante para esta pesquisa. Confesso que também eu comecei por admitir que São Teotónio tinha morrido em 1166, baseado no «feria VI» e que, portanto, poderia haver erro na inscrição ou leitura da Era indicada no sepulcro. A inscrição referida é a seguinte:

[in :] XII : K(a)L(endas) : M(a)RCII : OBIIT : DOmNUS : THEOTONIUS : P(r)IMUS : P(r)IOR : ET : PATER : MONASTEERII : SanCtE : + [crucis] : $\mathrm{E}(\mathrm{ra}): \mathrm{M}: \mathrm{C}[\mathrm{C}]$

\footnotetext{
${ }^{39}$ J. Saraiva, 1942, p. 44 e segs.

${ }^{40}$ A. Cappelli, 1998, p. 102, em correlação com a Páscoa que, nesse ano, ocorreu a 24 de Abril.

${ }^{41}$ J. Bollandus, 1736, Fevereiro, tomo III, pp. 105-118 e especialmente a p. 108: «moritur Febr. Feria 6 na. 1166».

${ }^{42}$ J. Encarnação, 1982, pp. 192-200.

${ }^{43}$ Ibid., p. 194.
} 
Actualmente faltam os extremos da inscrição, que parecem ter sido cortados, em data que desconhecemos, quando a tampa do sarcófago já se encontrava no altar da Capela de São Teotónio, só se lendo, no final da inscrição, «MC». O Prof. Mário Barroca considerou a data de «MC $[\mathrm{C}] »{ }^{44}$. Visitei a Igreja de Santa Cruz de Coimbra para analisar a inscrição ao longo da secção lateral da tampa do sarcófago, hoje a servir de mesa de altar na capela que se ergue na parede sul da Sala do Capítulo, e parece-me que, de facto, não há espaço para conter «MC[CIIII]», mesmo de forma condensada como aparece algumas vezes em epígrafes da época. Segundo M. Barroca, as semelhanças desta inscrição com a do sarcófago do bispo de Coimbra D. Miguel Salomão, que faleceu em 1180, levam a admitir que as duas tampas tenham sido executadas em momentos não muito afastadas entre si, pouco depois da morte do bispo de Coimbra.

Perante estes factos, os especialistas são unânimes em considerar que o erro na data da morte de São Teotónio não se encontra na indicação do ano, mas sim no dia da semana. O que poderia então levar à indicação do «feria VI»? Os erros nem sempre poderão ser explicados de forma satisfatória. Admitimos contudo uma possibilidade. A Era de 1200 assinalada na epígrafe da tampa do sepulcro de São Teotónio corresponderia, pois, ao ano da encarnação de 1162, segundo o cômputo de Pisa, hipoteticamente utilizado na Vita Theotonii, como se viu do estudo dos elementos rasurados da data de fundação do Mosteiro de Santa Cruz. Para a determinação do dia da semana, o ano da encarnação necessita sempre de duas letras dominicais. Começando a 25 de Março de 1161, os dias da semana desse ano até 31 de Dezembro, seriam determinados no calendário perpétuo pela letra dominical do ano do nascimento de 1161; um «A». Para os dias da semana, entre 1 de Janeiro a 24 de Março, deveria usar-se a letra dominical do ano de 1162; um «G», o que permitiria determinar correctamente que o 18 de Fevereiro tinha sido um domingo. É possível que a confusão entre o procedimento que normalmente se utilizava nos anos bissextos (que também necessita de duas letras dominicais) e o que se deve utilizar no ano da encarnação tenha induzido o uso indevido da letra dominical do ano de 1160; um «B». Daí resultaria a atribuição incorrecta de uma sexta-feira ao dia 18 de Fevereiro.

\footnotetext{
${ }^{44}$ M. Barroca, vol. II, tomo 1, pp. 288-291.
} 


\subsubsection{Sobre o mês em que decorreram as cerimónias fúnebres}

Merece a pena analisar a descrição da cerimónia fúnebre tal como foi descrita pelo discípulo anónimo, na busca de novos indícios sobre o problema da data da morte. $\mathrm{O}$ autor anónimo informa que Teotónio «foi colocado na cinza e no cilício, segundo a tradição cristã e, perfeitamente na posse das suas faculdades, encarou a morte com alegria» ${ }^{45}$. O Prof. Armando Martins fornece-nos uma descrição mais detalhada destes rituais de cinza e cilício, em que o moribundo era colocado no chão, pondo-lhe a cabeça sobre uma pedra dura, coberta de cinza, onde era deixado até expirar ${ }^{46}$. Como a morte de São Teotónio ocorreu na própria canónica - «in congregatione» - seriam celebradas trinta missas, nos trinta dias imediatos e, do primeiro ao sétimo dia, depois da morte, diariamente, por ele seria oferecido pela comunidade todo o ofício dos defuntos, missas, e matinas de nove lições. No trigésimo dia, depois do ofício, por ele se diriam cinco salmos e se faria procissão ao túmulo. No decorrer desses trinta dias, quotidianamente, na canónica seria dada aos pobres a ração completa - «prebenda» - a que o defunto teria direito, como se ainda estivesse presente. Estas cerimónias arrastar-se-iam assim até 18 de Março seguinte. São deste mês dois importantes documentos que beneficiam o Mosteiro de Santa Cruz. São eles a «Karta Liberatis» do bispo de Coimbra D. Miguel Salomão $^{47}$ e a doação de D. Afonso Henriques da mata de «Aljazede» (mata do Louriçal, no concelho de Pombal) ${ }^{48}$. As doações e privilégios não poderiam deixar de estar associadas ao facto, embora não o nomeiem expressamente. Aos dois documentos acima referidos, poderíamos ainda juntar a carta de D. Afonso Henriques ao Papa Alexandre II, em que declara ter fundado o Mosteiro de Santa Cruz de Coimbra para dele fazer mercê ao pontífice, e em que pede nova confirmação de todos os diplomas régios e episcopais a favor do mosteiro ${ }^{49}$. O mesmo se diga da suplicatio do bispo $\mathrm{D}$. Miguel ao Papa Alexandre III para confirmar a carta de liberdade concedida ao Mosteiro de Santa Cruz por ele em Março de $1162^{50}$.

\footnotetext{
${ }^{45}$ Vita Theotonii, ed. A. Nascimento, 1998, p. 199.

${ }^{46}$ A. Martins, p. 722 e seg..

${ }^{47}$ Livro Santo de Santa Cruz, ed. L. Ventura e A. Santiago, 1990, pp. 98-101.

${ }^{48}$ DMP-DR, vol. 1, tomo 1, pp. 358-359, doc. 280.

49 Ibid., pp. 359-360, doc. 281, com data crítica estabelecida no intervalo de Março de 1162 a Março de 1163.

${ }^{50}$ Livro Santo de Santa Cruz, ed. L. Ventura e A. Santiago, 1990, pp. 101-102. Sobre a suplicatio, a Prof. ${ }^{\text {a }}$ Leontina Ventura enviou-me amavelmente a seguinte informação adicional, que não encontrei publicada:
} 


\subsubsection{Os elementos cronológicos associados}

O último parágrafo da Vita Theotonii, na parte que ainda não analisamos, fornece-nos um conjunto de dados cronológicos associados à data em que São Teotónio morreu. Para a sua análise, é suficiente o recurso à tradução em português ${ }^{51}$ :

«Foi sepultado no dia décimo primeiro das mesmas calendas, no ano 56 do referido rei Dom Afonso I de Portugal, em cujo tempo recebeu a veste de Cristo, e no ano 35 do seu reinado. Viveu em votos de vida regular trinta e um anos. Cumpriu o tempo inteiro da sua vida, como ele referia, entre setenta e oitenta anos, segundo o padrão das Escrituras.»

Considerando a morte de São Teotónio em 1162, Afonso Henriques teria então 56 anos, o que coloca a data do seu nascimento em 1106. Contaria na mesma altura 35 anos do governo iniciado em 1128, contando ambos os extremos.

Os 31 anos de votos de vida regular corresponderiam ao tempo de vivência em Santa Cruz, contando também ambos os extremos, dado que a vida comunitária regular se iniciou em 24 de Fevereiro de $1132^{52}$. D. Teotónio seria formalmente substituído, em 1162, pelo seu sobrinho D. João Teotónio (1162-1181) que ele associara, desde 1152, ao governo da canónica. O período de trinta ou trinta e um anos, conforme se conte os extremos, incluiria assim os dez partilhados com o sobrinho, que o aliviou do peso do cargo no último decénio do priorado. A razão dessa delegação encontra-se expressa no texto da Vita Theotonii: «Foi o caso que vinte e um anos após a sua entrada no

«diz-se, no fim dela, que foi também objecto de petição de Afonso Henriques, confirmada por Teotónio e por outros que estão no mosteiro (petitio domni Alfonsi regis Portugalensis ad eundem apostolicum pro confirmatione suorum Teotonii et aliorum que fiunt in eodem monasterio). Ora, atendendo a que a carta de liberdade é, como disse, de Março de 1162, o pedido de confirmação (que não está datado) teria de ser, creio, posterior a Março. Ora se fora também feito por Teotónio é porque então ainda estava vivo. Mas uma pergunta se pode colocar: porque haveria o pedido de ser confirmado por Teotónio e não pelo que era à altura prior, D. João Teotónio?». Não sabemos mais nada sobre esta referência. Atendendo à cronologia apontada, apenas podemos admitir a deficiência de se nomear Teotónio em vez de João Teotónio.

${ }^{51}$ Vita Theotonii, ed. A. Nascimento, 1998, p. 201.

52 No prólogo do Livro de D. João Teotónio, não se consideram os extremos, contando-se trinta anos: «Cui nimirum per triginta annos primus pater domnus Theotonius prefuit», cit. de S. Gomes, 2007, p. $383, n^{\circ} 337$. 
mosteiro começou a contrair uma prolongada enfermidade corporal» ${ }^{53}$. Como o início da vida em comunidade foi em 1132, em 1152 se iniciava o $21^{\circ}$ ano. Tendo D. Teotónio continuado a viver no mosteiro «ao longo de dez anos que depois ainda teve de vida ${ }^{54}$, não se procedera, então, a nova eleição. É por este motivo que, nesse decénio, muitos dos diplomas atribuem o título de Prior ora a um ora ao outro dos Teotónios ${ }^{55}$. Um manuscrito de Santa Cruz de finais do século XIV, existente na Biblioteca Pública Municipal do Porto com o n ${ }^{\circ} 53$, refere a sua eleição formal em 1162, conforme se lê no fólio 75v: «Anno ab Incarnatione Filii Dej MCLXII post mortem domni Theotonij primi prioris, domnus Johannes in eius sede confirmatus est prior secundus» ${ }^{56}$. Associa-se assim, de forma segura, a eleição de D. João Teotónio ao mesmo ano da morte do primeiro prior.

A indicação da idade de São Teotónio entre os setenta e os oitenta anos, cuja precisão se revelava uma questão pouco significativa, corresponde aos quadros culturais próprios do homem e do clero medieval ${ }^{57}$. Se nasceu, como vulgarmente se aponta, em 1082, seria realmente em 1162 que se cumpriria aquela passagem da década dos setenta para a dos oitenta como, de uma forma hábil (que me foi sugerida pela Prof ${ }^{a}$. Leontina Ventura), se poderá ler o texto da Vita Theotonii. Mas a verdade é que a data de nascimento é deduzida do próprio texto ${ }^{58}$.

Podemos concluir, com excepção do dia da semana, que todos os dados cronológicos são aceitáveis e concorrem para que São Teotónio tenha morrido em 1162.

\subsection{Sobre a data de canonização}

O Prof. Aires Nascimento fixou a data crítica de produção da Vita Theotonii entre a data da morte de São Teotónio e a data da sua canonização, tendo obtido esta data de um

\footnotetext{
${ }^{53}$ Vita Theotonii, ed. A. Nascimento, 1998, p. 193.

${ }^{54}$ Ibid., p. 193. Esta será, porventura, a referência interna ao texto mais objectiva para determinar a morte de São Teotónio no ano de 1162 .

55 A. Martins, 2003, pp. 300-301. O governo de D. João Teotónio durante a vida de D. Teotónio está confirmado pelo livro de João Teotónio, fl. 2v: «Qui Iohannes iam antea per decennium et eo amplius a pio adhuc vivent patre tocius monasterii curam susceperat», cit. de A. Nascimento, 1998, pp. 220-221, nota 78 .

56 Trata-se do prólogo das disposições gerais tomadas no primeiro capítulo geral, de 1 de Maio de 1162 , decorrido em Santa Cruz, em que saiu um conjunto de Disposições de que a cópia mais antiga se encontra integrada na versão do Costumeiro, feita em 1382, por D. Vasco de Baião (Agostinho Frias, "O Mosteiro de Santa Cruz de Coimbra. Perspectivação Histórica”, in CLL, 1997, p. LXV). A sua existência foi dada a conhecer por A. Martins, 2003, p. 293.

${ }^{57}$ Cf. S. Gomes, 2007, p. 148, nº 604.

${ }^{58}$ A. Nascimento, 1998, p. $212, \mathrm{n}^{\circ} 9$.
} 
autor moderno já referido, D. Joaquim da Encarnação, que foi cónego regrante de Santa Cruz na segunda metade do séc. XVIII ${ }^{59}$. Note-se que a data de canonização, tal como este autor a refere, parece apresentar-se como uma data induzida, pois diz-nos que a canonização se realizou na data do primeiro aniversário da data em que faleceu: «se junctaram um anno depois de sua morte, no seu anniversario a 18 de Fevereiro, fosse de 1163 ou de $1167 \gg^{60}$. A hesitação quanto à data remete-nos para a pesquisa de outras fontes. Uma delas é a incontornável Crónica da Ordem dos Cónegos Regrantes, publicada um século antes, e que merece a pena reproduzir aqui ${ }^{61}$ :

«Vistos os muitos milagres que o Santo fazia, \& os que fez em sua vida, com a inquiriçaõ autentica, que tambem tirou em Viseu o Bispo D. Odorio, da santa vida, $\&$ obras mirauiljosass, que fez viuendo naquella Cidade, $\&$ aprouados os ditos milagres pello Bispo de Coimbra D. Miguel, se ajuntaraõ em o Mosteiro de S. Cruz o Arcebispo de Braga D. Ioaõ Peculiar, com os Bispos seus sufraganeos, a saber: o Bispo de Coimbra jà dito; o Bispo do Porto D. Pedro Rabaldiz; o Bispo de Viseu acima nomeado; \& o Bispo de Lamego D. Mendo, todos irmãos, porque todos eraõ Conegos professos do dito Mosteiro de Santa Cruz, \& filhos do Padre Santo Theotonio, \& examinada com grande consideraçã̃ a pureza da vida do Santo Prior, \& seus milagres, \& sua gloriosa morte, inuocando primeiro a graça do Espirito Santo, que nas Congregaçoens, \& Synodos Catholicos sempre assiste, à petiçaõ de todo o Clero, \& Pouo de Coimbra, \& de Viseu, \& de Leiria, \& á instancia do grande Rey D. Affonso Henriques, canonizou o Arcebispo Primàs de Braga como Metropolitano, juntamente cõ os Bispos acima ditos ao glorioso Prior Theotonio em 18. de Fevereiro do anno de 1163. dia do seu felice transito, cantandolhe em lugar do Anniversario dos defuntos, a Missa dos Santos Confessores: os justi meditabitur sapientiam, \&c. Cõ grande gosto; \& alegria vniuersal de todos os presentes, \&

\footnotetext{
${ }^{59}$ Ibid., p. 222, nos 90 e 92 e p. 254. Como nos alerta A. Martins (2003, p. 298, nota 774), D. Joaquim da Encarnação não cita nenhum documento comprovativo da data da canonização, referindo genericamente que usou os manuscritos do cronista D. José de Cristo (séc. XVI-XVII) e outras informações encontradas na livraria e no cartório do mosteiro (J. Encarnação, 1982, p. 199).

${ }^{60}$ J. Encarnação, 1982, p. 195.

${ }^{61}$ N. Santa Maria, 1668, p. 189. O Prof. António Cruz (1984, pp. 24-25) dá-nos a preciosa informação de que D. Nicolau de Santa Maria também usou os manuscritos de D. José de Cristo, acusando-o não só de falsário mas também de plagiador.
} 
particularmente do glorioso Rey D. Affonso Henriques, \& dos Conegos do Mosteiro de S. Cruz, como mais interessados na honra, \& gloria de seu Santo Prior; a qual canonizaçaõ aprouou, \& confirmou o Papa Alexandre III. Vivae vocis oraculo.»

A presença do arcebispo de Braga nas cerimónias fúnebres realizadas em Coimbra levanos a admitir que possa ter aproveitado a mesma deslocação para D. Miguel Salomão lhe prestar obediência como seu metropolita ${ }^{62}$. A referência à presença do bispo de Viseu, D. Odório (1147-1166) parece resolver a dúvida deixada no ar por J. da Encarnação quanto ao ano da canonização, que seria assim o de $1163^{63}$, pois que em 1167 já seria bispo D. Gonçalo (1166?-1169) ${ }^{64}$. Registe-se ainda a confusão relativamente ao nome do bispo do Porto, sendo de admitir que a fonte se referia apenas a D. Pedro, e que Nicolau de Santa Maria tenha deduzido erroneamente o apelido, pois não poderia ser D. Pedro Rabaldes (1138-1145) mas sim D. Pedro Senior (1154-1174). Em consonância com esta interpretação, D. Timóteo dos Mártires ${ }^{65}$, outro cronista dos Cónegos de Santo Agostinho, refere apenas D. Pedro ao falar da presença do bispo do Porto na canonização, acrescentando, todavia, mais alguns pormenores. Trata-se da indicação da presença na canonização de outras individualidades para além das referidas. São elas, o bispo de Orense, D. Pedro Seguino (1157-1169), o prior-mor do Mosteiro de São Vicente, D. Godinho e o mestre-escola da Sé de Lisboa, D. Álvaro, também eles «discípulos e companheiros no habito do mesmo padre Santo Theotonio». Sublinhe-se a participação do prior do Mosteiro de São Vicente de Fora, evidenciando a sua ligação a Santa Cruz, a reter para o estudo da influência da Vita Theotonii nos documentos do Mosteiro de São Vicente quanto à idade de D. Afonso I. A nova Ordem dos Cónegos Regrantes de Santo Agostinho, difundiu-se rapidamente, e após a conquista de Lisboa, em 1147, logo se pensou na fundação de S. Vicente de Fora ${ }^{66}$. A presença de cónegos de Santa Cruz no Mosteiro de São Vicente foi muito significativa no final do século XII. O primeiro prior foi D. Godinho Afonso, que saiu para bispo de

\footnotetext{
${ }^{62}$ Liber fidei, doc. 549, [1162?] (ed. A. Costa, 1978, p. 346).

${ }^{63}$ N. Santa Maria, 1668, p. 482, refere o assento no livro de óbitos do Mosteiro de Santa Cruz que D. Odório faleceu a 7 de Dezembro de 1166.

${ }^{64}$ Cf. M. de Oliveira, 1994, p. 311.

${ }^{65}$ T. Mártires, 1955 , pp. 45-46.

${ }^{66}$ J. Marques, 1990, p. 25.
} 
Lamego no ano de 1173. Outro cónego, D. Payo, foi prior castreiro, saindo depois para segundo bispo de Évora em 1180. Foi também prior castreiro D. Nicolau Annes Taveira, nomeado, posteriormente, bispo de Viseu pelo rei D. Sancho I, em $1193^{67}$.

Relativamente à data de canonização, aceitamos, pois, a data de 1163, embora as informações nas quais se baseia esta data se conheçam apenas por via indirecta.

\subsection{A data de produção do manuscrito da Vita Theotonii}

Procurando fazer o historial da datação atribuída ao manuscrito, o Rev. Prof. José Geraldes Freire ${ }^{68}$, apesar de nos dar conta que D. Joaquim da Encarnação pensava ser um «original autêntico»e que Alexandre Herculano o considera também «ao que parece, autógrafo», admitiu tratar-se de uma cópia dos finais do séc. XV, com base na data de 1476 inscrita no fl. $45^{\text {rb }}$. Não parece contudo ter razão, pois, de acordo com o Catálogo dos Códices da Livraria de Mão do Mosteiro de Santa Cruz de Coimbra, a mesma encadernação (séc. XVI-XVII) contém manuscritos de diferentes épocas, o que o terá induzido em erro. Para além da Vita Theotonii, atribuída aos séc. XII-XIII, inclui a Regra de Santo Agostinho e as Lendas dos Mártires de Marrocos, que se atribuem aos séc. XV e XVI, sendo que é no último que figura a data de $1476^{69}$.

O Prof. José Antunes considera que o texto original da Vita Theotonii deve ter sido escrito depois de 1175, possivelmente por D. Domingos Salomão ${ }^{70}$. A data de 1175 justifica-a atendendo a que no texto se refere que os monges de Santa Cruz foram chamados para orientar o Mosteiro de S. Vicente de Fora, o que considera só se ter verificado depois do seu sexto prior, isto é, por volta dessa data ${ }^{71}$. No entanto, o estudo da informação do texto da Vita Theotonii de que o presbítero Honório foi enviado a Lisboa com dinheiro para a construção da igreja de São Vicente, permite inferir que os contactos se iniciaram numa data anterior aquela, pois, as obras teriam começado no

\footnotetext{
${ }^{67}$ T. Mártires, 1958, vol. 2, pp. 85-90.

${ }^{68}$ J. Freire, 1984, p. 91.

${ }^{69}$ CCL, 1997, p. 163.

70 As duas hipóteses não são compatíveis, dado que D. Domingos Salomão faleceu a 12 de Julho de 1169 (T. Mártires, 1955, p. 11). Sabemos pela Vita Tellonis (ed. A. Nascimento, 1998, p. 71 e p. 77, nº 9) que Domingos e, mais tarde, o seu irmão Pedro Salomão obtiveram em São Rufo de Avinhão cópias dos textos necessários à vida da canónica. Pela forma impessoal como o autor da Vita Theotonii (ed. A. Nascimento, 1998, p. 169, n 12) se refere ao envio de emissários a Avinhão, não nos permite supor que seja um deles.

${ }^{71}$ J. Antunes, 1995, p. 67, no 129.
} 
ano de $1148^{72}$, tendo como superintendente o referido cónego, que faleceu neste mosteiro em $1161^{73}$.

Por sua vez, o Prof. Aires Nascimento considera o manuscrito da Vita Theotonii uma cópia com intervenções menos hábeis de alguém por volta de 1180, apresentando para o efeito três argumentos ${ }^{74}$. O primeiro tem a ver com a referida falta de correspondência do dia da semana, «feria VI», com o dia da morte de São Teotónio a 18 de Fevereiro de 1162. Depois de toda a atenção que nos mereceu o assunto, não encontrei, em si mesmo, nenhum indício que levasse a admitir que pudesse ter tido origem num copista e não no autor. Aliás, penso que a admissão pelo Prof. A. Nascimento de se tratar de erro de copista, se apoia essencialmente no segundo argumento que refere: o facto de o bispo de Coimbra, D. Miguel Salomão, aparecer no texto como cónego regular já no momento em que preside às exéquias de Teotónio ${ }^{75}$. Entendendo que essa situação apenas se verifica depois da sua resignação em 1176, concluiu pela admissão de que esta parte final do texto foi retocada por alguém menos cuidadoso em evitar anacronismos e com pouco rigor em reconstituir factos e datas ou também em rever a cópia. Todavia, este argumento poderá não ser válido, pois é possível que D. Miguel Salomão tenha sido cónego regrante de Santa Cruz antes de ser bispo de Coimbra ${ }^{76}$. No "Livro das Vidas dos Bispos da sé de Coimbra”, escrito no século XVI pelo cónego Pedro Álvares Nogueira $^{77}$, refere-se que D. Miguel Salomão:

«se meteo no mosteiro de santa Cruz da ordem de santo Agost. ${ }^{\circ} \mathrm{q}$ entam florecia nesta Cidade onde deo taes mostras de sua santidade he uirtude que na primeira uacante foi elleito bpõ cõ $\mathrm{m}^{\text {ta }}$ satisfacaõ de todo pouo, porque em tudo trabalhaua por imitar o exemplo do gloriosso padre Sam Teotonio prior do mosteiro de quē era muito deuoto».

\footnotetext{
72 A. Nascimento (1998, pp. 183 e 219, $\mathrm{n}^{\text {o }}$ 67) e Indiculum fundationis Monasterii S. Vicentii (ed. A. Nascimento, 2001, p. 197): «como se deduz, pois, do que ficou dito, o mosteiro de S. Vicente de Lisboa foi fundado pelo rei Afonso e construído no ano de 1148 da encarnação de nosso Senhor Jesus Cristo, que é bendito pelos séculos».

${ }^{73}$ T. Mártires, 1955 , pp. $4-5$ e p. 83.

${ }_{75}$ A. Nascimento, 1998, p. $211, \mathrm{n}^{\circ} 3$.

75 Vita Theotonii, ed. A. Nascimento, 1998, p. 209: «Dehinc in capitulo a uenerabili uiro domno Michaele Colimbriensium episcopo et Sancte Crucis canonico».

${ }^{76}$ É também a opinião de A. Martins, 2003, pp. 285-286.

${ }^{77}$ A. Madahil (ed.), 1942, pp. 52-55.
} 
Diga-se ainda que os grandes privilégios dados por D. Miguel Salomão ao mosteiro em 1162, logo no primeiro ano do seu episcopado, podem estar relacionados com a sua procedência de Santa Cruz.

O terceiro argumento do Prof. Aires Nascimento passa pela consideração que o epíteto de «beatissimus» (santo) no título da Vita Theotonii, não envolve uma informação cultual, mas apenas um juízo de santidade. De acordo com a sua opinião há que atribui-lo não ao original, mas à cópia, esta derivada de momento posterior ao da canonização de Teotónio, que o texto ainda não conhece nem nele estão presentes narrativas de milagres post mortem que dessem pretexto a uma promoção do culto ${ }^{78}$. Mas não podemos negar que estamos na iminência de uma canonização, não só pela data em que se realizou, no primeiro aniversário da sua morte, que nos permite pensar que foi desde logo planeada a seguir ao funeral, mas também por expressões que se encontram no texto como «famulus Dei» (servo de Deus) e «sucut nobis sanctus referebat» (segundo o santo nos referia) ${ }^{79}$. A instrução do processo de canonização parece estar a decorrer, conforme transparece da passagem em que o autor nos refere que «sanctissimos illius actus senioribus meis ac per hoc sapientioribus plenarie describendos relinquo» (deixo que a descrição pertinente dos actos da sua excelsa santidade seja feita pelos meus anciãos que por isso mesmo são mais sabedores) ${ }^{80}$. Em meu entender, este passo insinua não só que era um jovem discípulo, mas também a existência de um grupo de anciãos responsável pela condução do processo de canonização. Podemos admitir facilmente que o autor antecipasse o evento, registando-o desde logo, em mais uma demonstração da finitude ad saecula saeculorum que envolvia toda a produção do scriptorium crúzio ${ }^{81}$.

Avaliadas que foram as diferentes propostas de datação do manuscrito, concluímos pela admissibilidade de a Vita Theotonii ser um autógrafo; a hipótese primeiramente avançada por Alexandre Herculano, o que não quer dizer que todas as suas informações sejam fidedignas. Se um dia se identificar o autor gráfico do texto, creio que estará também encontrado o seu autor intelectual. Apesar de admitirmos que o

\footnotetext{
${ }_{78}^{78}$ A. Nascimento, 1998, p. $9, \mathrm{n}^{\mathrm{o}} 1$ e p. $211, \mathrm{n}^{\mathrm{o}} 1$.

${ }^{79}$ Vita Theotonii, ed. A. Nascimento, 1998, pp. 150-151 e pp. 156-157, respectivamente. J. Freire, 1984, p. 95, referiu estas expressões para defender que a obra foi redigida depois da canonização de São Teotónio.

${ }^{80}$ Ibid., pp. 140-141.

${ }^{81}$ Cf. é referido pelo Prof. Saul Gomes no cólofon da sua volumosíssima dissertação (2007, pp. 930-931).
} 
texto foi produzido em cerca de 1162, não será de considerar a autoria de D. Domingos Salomão, proposta por José Antunes, pois, nesta data, apesar de ainda estar vivo, já não seria um jovem discípulo. O perfil do candidato à autoria intelectual do texto parece corresponder mais ao de D. Paio, tal como este é descrito por Frei Timóteo dos Mártires $^{82}$ : (1) discípulo de São Teotónio; (2) «bom letrado de grande virtude», em concordância com as características do texto e com a sua carreira; (3) Prior Crasteiro do Mosteiro de São Vicente (entre 1174 e $1180^{83}$ ), pelo que poderia ser ele o veículo de transmissão da tradição do nascimento de Afonso Henriques em 1106 para esse mosteiro, conforme veremos mais tarde; (4) seria bispo de Évora em 1181, afastando-se ainda mais de Santa Cruz onde, alguns anos mais tarde, surgiria uma tradição diferente sobre a data de nascimento do nosso primeiro rei; (5) faleceu a 8 de Setembro de 1204, podendo, portanto, ser um jovem e talentoso discípulo em 1162. A confirmação ou não desta possibilidade poderá ser dada pela análise comparativa das características gráficas da Vita Theotonii com a eventual documentação existente escrita por D. Paio, como cónego de Santa Cruz, prior crasteiro de S. Vicente ou bispo de Évora, que não foi objecto de estudo neste trabalho.

\section{As tradições da data de nascimento de Afonso Henriques}

\subsection{A tradição associada ao ano de 1106}

\subsubsection{Translatio et Miracula S. Vincentii}

Se tomarmos como elemento útil as referências ao rei D. Afonso Henriques e a seu filho D. Sancho, associado ao trono nos últimos anos do reinado de seu pai, teremos que admitir que o Translatio et Miracula S. Vincentii foi redigido a seguir à transladação das relíquias em 1173 e antes de $1185^{84}$. É o testemunho de um contemporâneo, Mestre Estevão, que veio a ser investido na dignidade de chantre da Sé de Lisboa (como declara o incipit e como é plausível pelas qualidades que o próprio texto revela), embora, como refere a Prof ${ }^{a}$. Maria João Branco, ele próprio possa ter sido também cónego regrante de São Vicente ${ }^{85}$. De todas as fontes coevas que fazem referência à idade de Afonso

82 T. Mártires, 1955, p. 88.

${ }^{83}$ Cf. C. Silva, 2002, p. 70.

${ }^{84}$ A. Nascimento atribui a sua composição a cerca do ano de 1180 ("Milagres de São Vicente", in DLM, 2000, pp. 458-459).

${ }^{85}$ M. Branco, "Introdução”, in A conquista de Lisboa aos mouros (ed. A. Nascimento, 2001, p. 50). 
Henriques, esta é a única cujo nome do autor é conhecido. O historiador jesuíta Gonzaga de Azevedo valoriza especialmente este facto $^{86}$ :

«Concorrem, também, em mestre Estevão, curso e formação literária, indicada pelo título de magister, e o ser coevo; nada lhe falta, pois, para ser reputada testemunha digna de fé».

O autor apresenta-se não só como testemunha dos factos, mas defendendo a posse das relíquias pela Sé de Lisboa, contra as pretensões dos cónegos regulares que as queriam levar para o Mosteiro de S. Vicente de Fora ${ }^{87}$. A cronologia da trasladação é apresentada no texto ${ }^{88}$ :

«Regista-se, pois, e celebra-se em alegria e grata memória o dia em que, segundo consta, o corpo do grande S. Vicente foi transladado para a igreja de Lisboa. Essa transladação festiva e solene está marcada no dia 15 de Setembro do ano do Senhor de 1173, no ano $45^{\circ}$ do reinado do rei Afonso, aos 67 anos de sua vida, co-reinando [conregnante] Sancho, filho do mesmo rei, de 19 anos, um jovem de carácter admirável, 26 anos depois de tomada a cidade.»

Fazendo a validação da cronologia aqui apontada, à data da trasladação, obtemos:

- Anos de reinado: $1173-45=1128$;

- Anos decorridos desde a conquista de Lisboa: 1173-19=1147;

- Idade de Sancho: $1173-19=1154^{89}$;

e finalmente:

- Data de nascimento de Afonso Henriques: 1173-67=1106, em perfeita consonância com a informação da Vita Theotonii.

Existem ainda outros elementos caracterizadores de uma possível dependência

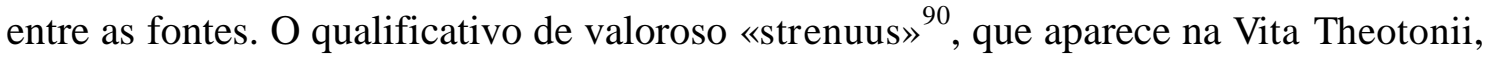

${ }^{86}$ G. Azevedo, 1940, vol. III, p. 242.

${ }^{87}$ A. Nascimento, 1988, pág. 24.

${ }^{88}$ Translatio et Miracula S. Vincentii, ed. A. Nascimento, 1988, pp. 40-41 e a tradução revista por J. Mattoso, 2007, pp. 325-326.

${ }^{89}$ Cf. Annales D. Alfonsi Portugallensium regis, «Era de 1192 (=1154): O rei D. Sancho, filho do rei Afonso e da rainha D. Matilde, nasceu na noite de S. Martinho, a uma $5^{\text {a }}$ feira. Assim, no seu baptismo tomou o nome Martinho mas depois ele foi chamado de Sancho. Nasceu no $26^{\circ}$ ano da sua pátria.» (traduzido da ed. M. Blöcker-Walter, 1966, p. 158). A data do nascimento de Sancho corresponde ao dia 11 de Novembro de 1154, cf. J. Mattoso, 2007, p. 383.

${ }^{90}$ Referido por J. Antunes, 1999, p. 19. 
sobre a sua invencível bravura na guerra «ob inuictissimam eius in martiis congressionibus strenuitatem» ${ }^{91}$ tem correspondência nos Miracula S. Vicenti, com sua intrepidez sobremaneira eminente «strenuitas admodum insignis effulsit» ${ }^{92}$ e nos Annales Domni Alfonsi Portugallensium regis, de que trataremos mais tarde, que o toma como homem intrépido no combate $\ll$ vir armis strenuus ${ }^{93}$.

Observamos ainda que o uso, pouco frequente, do topónimo Lusitânia mencionada na Vita Theotonii ao apresentar um engrandecido monarca «... qui tunc infans dux Portugalis erat, sed processu temporis et diuini muneris largitate, post tocius pene Lusitanie et ex parte Gallecie rex est effectus illustris.». A expressão é usada também no mesmo sentido no Translatio et Miracula S. Vicentii - «Lusitania quoque titulis eius ascribit»- e nos Annales D. Alfonsi, na descrição da invasão do emir de Marrocos, em 1184 «..., et sic denique subiugata sibi tota Lusitania usque Dorium» ${ }^{94}$. Pode-se admitir, portanto, uma tradição comum a estes três textos.

\subsubsection{Indiculum F undationis Monasterii Beati Vincentii Vlixbone}

A produção da crónica da tomada de Lisboa aos mouros e da fundação do Mosteiro de S. Vicente, escrita em latim por um anónimo, terá tido lugar no scriptorium do Mosteiro de S. Vicente de Fora em Lisboa. Merece a pena transcrever o início da narrativa, que contém uma referência à data que procuramos ${ }^{95}$ :

«No ano, pois, da Encarnação do Senhor de 1147, o cristianíssimo rei de Portugal, Afonso, filho do conde Henrique e da rainha Teresa, extraordinário e decidido exterminador dos inimigos da cruz de Cristo, no ano 18 do seu reinado, ou, por outra, a os 40 anos de idade, reuniu o seu exército contra os sarracenos, como era seu costume todos os anos, acercou-se de Lisboa, então cidade deles, e sitiou-a no mês de Junho, montando acampamentos em seu torno.»

\footnotetext{
${ }^{91}$ Vita Theotonii, ed. A. Nascimento, 1998, no 19, p. 178.

${ }^{92}$ Translatio et Miracula S. Vincentii, ed. A. Nascimento, 1988, p. 28.

93 Annales D. Alfonsi Portugallensium regis, ed. de M. Blöcker-Walter, 1966, p. 151.

${ }^{94}$ O. Gama, 2009.

${ }^{95}$ Indiculum Fundationis Monasterii Beati Vincentii Vlixbone, ed. A. Nascimento, 2001, p. 179.
} 
A contagem dos anos de reinado, ao subentender o início do reinado de D. Afonso Henriques em 1129 (=1147-18), difere das outras fontes. Se tomarmos 1128, como é mais usual, a mesma contagem daria 19 anos, como acontece aliás no De expugnatione Scallabis. Do texto se retira o ano de nascimento em 1107 (=1147-40), mas possível de harmonizar para 1106, se o nascimento foi posterior ao mês de Junho.

$\mathrm{Na}$ parte final do texto, uma outra referência dá-nos a indicação da data em que este documento foi escrito ${ }^{96}$ :

«..., durante a governação do rei Sancho, filho do referido rei Afonso, governação essa que leva já três anos decorridos no ano da Encarnação do senhor de 1188.»

Como se vê, o texto tem data de composição certa em 1188, embora o testemunho manuscrito que possuímos seja cópia dos inícios do século XIII ${ }^{97}$. A referência a Sancho, que também aparece no Translatio et Miracula S. Vincentii induz a que pelo menos a parte final do Indiculum tenha sido influenciada por aquele texto, como possivelmente também aconteceu no que respeita à idade de D. Afonso Henriques.

\subsubsection{Martirológio da Sé de Lisboa}

Refere ainda o ano de 1106 um martirológio da Sé de Lisboa, citado por D. José Barbosa, aonde, a seis de Dezembro, se lê na margem «estas formaes palavras, de que dou a copia com a sua mesma orthographia ${ }^{98}$ :

«Eodem die sub era 1222. Obijt illustrissimus Rex Portugallensium doñus Alfonsus año vitæ suæ septuagesimo octavo. Regni vero ejus quinquagesimo sexto. Qui inter plurima militiæ suæ gesta Civitatem hanc à potestate Sarracenorum eripuit. \& operis hujus Ecclesiæ ad honorem Dei, ac memoriam beatæ Virginis regali munificentia extitit fundator, \& factor.»

Continua o mesmo autor:

\footnotetext{
${ }^{96}$ Ibid., p. 197.
}

${ }^{97}$ A. Nascimento (2001, notas da tradução, $n^{\circ} 1$, pág. 200) considera que a não referência no texto a aspectos como o da disputa das relíquias de $\mathrm{S}$. Vicente, levam a pensar que a sua redacção primitiva possa ser anterior a esse episódio que data de 1173.

${ }_{98}$ J. Barbosa, 1727, pp. 80-81. 
«Dizem em Vulgar. No mesmo dia na era de 1222. morreo o Illustrissimo Rey dos Portuguezes D. Affonso aos 78. annos da sua idade, e aos 56. do seu reinado. O qual entre as muitas acções da sua vida, ganhou aos Mouros esta Cidade, e para honra de Deos, e em memoria da Virgem Maria fundou, e fez com Real magnificencia a obra desta Igreja.»

A Era de 1222 corresponde ao ano do nascimento de Cristo de 1184, pelo que subtraindo 78 anos, remeteria o nascimento para 1106, em sintonia com a Vita Theotonii e as fontes do Mosteiro de São Vicente e da Sé de Lisboa. Note-se contudo a deficiência de um ano na indicação da data da morte de D. Afonso Henriques, pois esta só ocorreu em 1185. Apesar disso, constata-se a coerência interna dos dados cronológicos apresentados, sendo correcta a contagem do número de anos de reinado, desde 1128 até 1184 .

Apesar do empenho que colocámos na busca do martirológio, e do apoio dado por vários especialistas de que nos socorremos, não o encontramos, o que nos levou a atribuir a sua perda ao terramoto de Lisboa de 1755. Como também não conseguimos encontrar mais nenhuma referência a este martirológio, hesitamos em inclui-lo neste trabalho. Todavia, para além das conclusões que se poderão retirar numa futura análise crítica do texto citado, as referências que lhe são feitas por D. José Barbosa, de que se trata de um manuscrito «antiquíssimo» e a importância que atribui à fonte ao sublinhar «de que [dele] se naõ lembrou» Frei António Brandão, permite-nos intuir alguma ancianidade. Acabamos assim por decidir inclui-lo para memória futura.

\subsection{A tradição associada ao ano de 1110}

\subsubsection{De expugnatione Scallabis}

O De expugnatione Scallabis é um texto de celebração da tomada de Santarém aos mouros, em que o narrador se reveste da personagem de Afonso Henriques para conduzir a narrativa na primeira pessoa. Recentemente, o Prof. Aires Nascimento apresentou uma nova edição crítica deste documento com o título que detinha anteriormente este manuscrito medieval «Quomodo sit capta Sanctaren a rege Alfonso 
comitis Henrici filio» ${ }^{99}$. A sequência dos momentos da acção da conquista de Santarém dá-nos um relato de pormenor que parece transmitir o testemunho de alguém que acompanhou ou refez todo o percurso da acção. O Prof. Aires Nascimento considera assim que terá sido escrito por algum membro do séquito que participou no ataque, ou por alguém que recolheu impressões de um testemunho directo. Chama ainda à colação um trabalho de Armando de Sousa Pereira ${ }^{100}$ onde se admite que represente a memória de um companheiro do rei que depois tenha professado no Mosteiro de Santa Cruz. O Prof. José Mattoso reforça a ideia de que se trata de um escrito único em toda a historiografia portuguesa, por não existir nenhuma outra narrativa de uma acção militar feita pelo rei na primeira pessoa ${ }^{101}$. Mas, como refere, o que permanece por explicar é a atribuição da autoria ao próprio rei e o uso da narrativa na primeira pessoa. $\mathrm{O}$ seu autor seria da Sé de Coimbra, segundo Aires Nascimento, ou de Santa Cruz, segundo Lindley Cintra $^{102}$. Esta distinção é, para mim, pouco relevante se atendermos à profunda influência exercida pela comunidade crúzia no restante clero, na segunda metade do século XII, para onde saiu um número significativo de bispos e priores.

$\mathrm{Na}$ descrição dos factos, a determinação do tempo faz-se de forma explícita, com pormenores que fornecem quase a nossa desejada certidão civil do rei ${ }^{103}$ :

«Foi ela [Santarém] tomada a quinze de Março, ao raiar de um sábado, na era de 1185 (a. D. 1147), ano esse em que os Mouros, a quem se dá o nome de Mozamida, deram entrada em Espanha e destruíram a cidade de Sevilha, e em que eu tinha quase completado 37 anos de idade e 19 de reinado, ainda não era passado um ano inteiro sobre o meu casamento com Mafalda, filha do conde Amadeu, de quem haveria de nascer o meu filho primogénito, Henrique, a 5 do mesmo mês em que a cidade foi tomada segundo esta sequência de acontecimentos.»

\footnotetext{
${ }^{99}$ Quomodo sit capta Sanctaren ciuitas a rege Alfonso comitis henrici filio, ed. A. Nascimento, 2005, pp. 1217-1232.

${ }^{100}$ A. Pereira, 1996, pp. 301-302.

101 J. Mattoso, 2007, pp. 237-238.

${ }^{102}$ L. Cintra, 1951, pp. CCCXCII-CCCXCIV, No 214.

${ }^{103}$ Quomodo sit capta Sanctaren, ed. A. Nascimento, 2005, p. 1229.
} 
Obtemos assim, desta forma espantosa, na pessoa do próprio visado, a informação que nasceu em 1110, depois de 15 de Março. Mais se diz que vai no $19^{\circ}$ ano de reinado, o que é o mesmo que dizer que estes se contam a partir de 1128, o ano da batalha de São Mamede, que ocorreu a 24 de Junho ${ }^{104}$. Como veremos à frente, a consideração do ano de 1128 como o começo do reinado de D. Afonso Henriques encontra-se expressa em muitas das notícias dos Annales D. Alfonsi Portugalensius regis.

Os almóadas tomaram Sevilha aos almorávidas em 17 ou 18 de Janeiro de $1147^{105}$, o casamento com D. Mafalda foi provavelmente a 31 de Março de 1146, portanto quase a fazer um ano, conforme é referido no texto ${ }^{106}$. O primeiro filho do casal régio foi um menino chamado Henrique, que teria morrido cedo, pois este é o único registo do primogénito do rei D. Afonso Henriques. Torna-se evidente a preocupação do narrador em caracterizar o ano da tomada de Santarém, por indicações cronológicas coerentes entre si e até bem informadas. O tom parece ser o de recordar um acontecimento passado, numa perspectiva de exaltação heróica de um acto de conquista, amplificado pelo decorrer do tempo, como sucedeu relativamente à batalha de Ourique registada nos Anais de D. Afonso por volta de $1185^{107}$. Registo este que seria da mesma altura da produção da narrativa da tomada de Santarém. De acordo com a opinião do Prof. Luís Krus, esta poderia ter sido escrita na sequência do cerco de Santarém pelas hostes almóadas em $1184^{108}$.

\footnotetext{
${ }^{104}$ A importância da batalha de S. Mamede está subjacente ao título de uma conferência proferida por José Mattoso em 1978 na cidade de Guimarães - «A primeira tarde portuguesa» - numa alusão ao painel da autoria de Acácio Lino, que representa a batalha de S. Mamede e se encontra no Palácio da Assembleia da Republica (J. Mattoso, 1985, pp. 11-35).

${ }^{105}$ Fundación El Legado Andalusi, 2003, p. 205 e B. Reilly, 1998, p. 95.

${ }^{106}$ Sobre a data de casamento de Afonso Henriques e o nascimento do primeiro filho, veja-se J, Mattoso, 1997 , p. 220.

107 A respeito da evolução da narrativa da Batalha de Ourique, consulte-se Mattoso, 2007, pp. 157-168.

108 L. Krus, 2000, p. 515. No mesmo sentido, B. Reilly (1998, p. 96, no 20) considera a Tomada de Santarém como um texto de natureza literária baseado em contos populares e, portanto, afastado dos acontecimentos que descreve. Parece-nos menos plausível a hipótese avançada por A. Nascimento, 2005, p. 1223, que considera que a sua composição possa ter sido realizada muito próximo dos acontecimentos, ainda no contexto da emoção provocada pela conquista, e antes da tomada de Lisboa, no mesmo ano, a 25 de Outubro de 1147, com o argumento que esta remeteria, mais tarde, a notícia da tomada de Santarém para segundo plano. Podemos contrapor a este argumento que o texto, a ser escrito imediatamente antes da conquista de Lisboa, não poderia deixar de nomear esse objectivo, pois quando a armada dos Cruzados vinda de Dartmouth chegou ao Porto, no dia 16 de Junho de 1147, já o bispo da cidade tinha instruções do rei para os receber, e lhes propor participarem na conquista de Lisboa (J. Mattoso, 2007, p. 237).
} 
Assinalando fortes pontos de contacto entre a De expugnatione Scallabis e a Vita Theotonii, o Prof. Lindley Cintra atribuiu-lhes uma autoria comum. Segue a sua $\operatorname{argumentação~}^{109}$ :

«O estilo vivo, variado, muito pessoal do discípulo do primeiro abade do Mosteiro de Coimbra, que escreveu a sua vida por fins do séc. XII, inícios do séc. XIII, permite a hipótese de também se lhe dever o De expugnatione. Nos dois textos se manifesta a mesma admiração incondicional pelo Rei. E a hipótese é principalmente reforçada: $1 .^{\circ}$, pelo facto de, num como noutro texto, se aludir, em termos perfeitamente concordes, à revelação dos objectivos da expedição, feita pelo Rei a S. Teotónio, e às orações com que este e os seus monges acompanharam a arriscada empresa; $2^{\circ}$, por, na boca do Santo, na sua biografia, na do Rei, no relato da conquista, surgirem precisamente as mesmas citações da Biblia: «Domine, Domine... omnipotens qui muros iherico sine gladio et arco subrui fecisti qui etiam ad precem iosue contra gabon solem stare precepisti» (Vita S. Theotonii, PMH, Script., I, pg. 86 b 52-55); «Testor deum celi, oculis cuius nuda et aperta saunt omnia, quia nec muros iericho subrutos, nec solis stationem prece iosue ad gabaon in comparationem huius in me pietatis et misericordie facti pro miraculis duco»(De expugnatione Scalabis, PMH, Script., I, pgs. 94 a 30-33). Não é de crer que estas coincidências sejam puramente ocasionais.»

Opinião diferente tem Aires Nascimento, não só porque considera o texto do De expugnatione Scallabis anterior à Vita Theothonii, mas também porque interpreta as semelhanças por dependência e acentua as diferenças ${ }^{110}$. Invocando os preparativos de D. Afonso Henriques para a tomada de Santarém, salienta que no De expugnatione Scallabis (narrado, como vimos, pelo rei na primeira pessoa), se fazem com uma ampla envolvência «dos cónegos de Santa Cruz, a quem dei conhecimento da nossa empresa e em quem tenho confiança, como também por parte de outro clero juntamente com todo o povo», enquanto o envolvimento pressuposto na Vita Theotonii se fica no sigilo de

${ }^{109}$ L. Cintra, 1951, vol.1, pp. CCCXCII-CCCXCIV, No 214.

${ }^{110}$ A. Nascimento, 2005, p. 1221. 
Teotónio. Por outro lado, salienta a profusão de palavras árabes no De expugnatione Scallabis e o seu aparecimento ocasional na Vita Theotonii.

Embora considerando, como fizemos, o texto do De expugnatione Scallabis posterior à Vita Theotonii, continuam válidas as diferenças apontadas por Aires Nascimento e, portanto, a não se considera provável uma autoria comum dos dois textos. Só assim se compreende que a anomalia mais acima acentuada de, no segundo destes textos, se situar a morte de S. Teotónio numa sexta-feira, seja a possível origem do equívoco, implícito no primeiro texto, acerca do ano da morte, atribuída a 1166. Subtraindo os 56 anos de idade do rei ao ano assim obtido, fixou-se o seu nascimento em 1110 e portanto, que ia nos 37 anos de idade quando tomou Santarém. Escrito num período crítico da história de Portugal, entre a invasão sarracena de 1184 e a morte do fundador, podemos admitir que o texto do De expugnatione Scallabis desempenhou um papel extremamente importante na transmissão de uma forte ideologia de combate. Estava lançada, em terreno fértil, a semente da nova tradição do nascimento de Afonso Henriques em 1110.

\subsubsection{As fontes analísticas}

Os Anais são uma relação de factos, segundo a ordem dos anos em que os mesmos ocorrem. Os mais antigos Anais portugueses existem em duas versões: a longa, representada pela segunda parte do Livro de Noa de Santa Cruz e pela chamada Chronica Gothorum; e a breve, pela primeira parte do mesmo Livro de Noa e por uma cópia contida na Summa chronicarum procedente de Alcobaça. A versão longa foi continuada na recensão da Chronica Gothorum por notícias até ao ano de 1122, e depois por outra série sobre Afonso Henriques (até 1184); foram publicadas separadamente, a primeira, sob o nome de Annales Portugalenses veteres, por Pierre David, em 1947, e a segunda, sob o nome de Annales D. Alfonsi Portugallensium regis, por Monica BlöckerWalter, em 1966. Quanto à recensão breve, publicada por P. David, foi também continuada até 1168, existindo igualmente em duas versões: uma na primeira parte do Livro de Noa e outra nos Annales lamecenses (da Sé de Lamego) ${ }^{111}$. A recensão breve, tal como foi reconstituída por P. David, não contém qualquer referência à data de nascimento de Afonso Henriques. Na primeira série da versão longa, existem duas

\footnotetext{
${ }^{111}$ J. Mattoso, “Anais”, in DLM, 2000, pp. 50-51.
} 
referências que o mesmo autor considera que podem ter sido uma interpolação posterior aos Anais ${ }^{112}$.

\subsubsection{Annales D. Alfonsi Portugalensius regis}

Os Anais de D. Afonso, Rei dos Portugueses, constituem uma verdadeira apologia do primeiro rei de Portugal e aproximam-se já do género cronístico; exprimem bem a estreita vinculação entre Santa Cruz e o seu régio fundador: foram provavelmente redigidos imediatamente depois da morte de Afonso Henriques, e a seguir à destruidora invasão almóada de 1184, que ameaçou seriamente a cidade de Santarém; representam, como outros textos historiográficos redigidos em Santa Cruz pela mesma época, uma fonte imbuída do espírito de cruzada, que até então se exprimia raramente em textos e documentos portugueses, apesar da guerra santa ${ }^{113}$.

A nossa atenção recai sobre as duas primeiras notícias dos Anais. A primeira é a que descreve a investidura de Afonso Henriques como cavaleiro. Tomando o seu texto vertido para português ${ }^{114}$ :

«Era de 1163 [1125]. O ínclito infante D. Afonso, filho do conde Henrique e da rainha D. Teresa, neto de D. Afonso, tendo cerca de 14 anos de idade, estando na Sé de Zamora, no dia santo de Pentecostes, tomou de cima do altar as armas militares e vestiu-se e cingiu-se a si próprio diante do altar, como é costume fazerem os reis.»

Este texto aponta o nascimento de Afonso Henriques em 1111, ou até em 1110, admitindo que ainda não tinha completado 15 anos quando se armou cavaleiro, a 17 de Maio $^{115}$. Contudo, se tomarmos o nascimento em 1106, como nos é referido na Vita

\footnotetext{
112 P. David, 1947, p. 302. São as que se encontram na PMH, Chronica Gothorum, SS. 11, uma directa, refere o nascimento de Afonso Henriques em 1113 «Era MCLI. Natus fuit Infans Alfonsus Comitis Henrici et Regine D. Tarasie filius Regis D. Alfonsi nepos» e outra, indirecta, sobre a morte do conde D. Henrique em 1114 «Era MCLII. Cal. Maii obiit Comes D. Henricus». Posteriormente, R. Azevedo (1958, nota 1, pp. LV-LVI) dá grande plausibilidade à conjectura de J. Ribeiro (1810, pp. 226-227) de que no arquétipo da notícia da morte do conde D. Henrique estivesse «Era MCL. II Cal. Maii», o que coloca a morte no dia 30 de Abril de 1112, harmonizando-se perfeitamente com os últimos documentos em que comparece o conde de Portugal e os primeiros que revelam o seu desaparecimento.

113 J. Mattoso, "Anais", in DLM, 2000, p. 51.

${ }^{114}$ Usamos a tradução de J. Mattoso, 2007, p. 54.

115 Ibid., p. 380.
} 
Theotonii, tem de se corrigir a data da investidura para 1120. Desde esta data até 1127, Afonso Henriques outorgou ou subscreveu, a quase totalidade dos diplomas da sua mãe. Que eu saiba, nunca ninguém relacionou estes factos. Neste contexto, dir-se-ia que a cerimónia correspondia a uma iniciativa de sua mãe para assegurar os direitos do jovem Afonso à sucessão, e não em oposição a ela, como uma data mais tardia poderia insinuar.

A segunda notícia dos Anais de D. Afonso, Rei dos Portugueses, refere-se à descrição da batalha de São Mamede ${ }^{116}$ :

«Na era de 1166 [ano de 1128], no mês de Junho, na festa de S. João Baptista, o ínclito infante D. Afonso, filho do conde Henrique e da rainha D. Teresa, neto do grande imperador da Hispânia, D. Afonso, com o auxílio do Senhor e por clemência divina, e também graças ao seu esforço e persistência, mais do que à vontade ou ajuda dos parentes, apoderou-se com mão forte do reino de Portugal. Com efeito, tendo morrido seu pai, o conde D. Henrique, quando ele era ainda criança de dois ou três anos, certos [indivíduos] indignos e estrangeiros pretendiam [tomar conta] do reino de Portugal; sua mãe, a rainha D. Teresa, favorecia-os, porque queria, também, por soberba, reinar em vez de seu marido, e afastar o filho do governo do reino. Não querendo de modo algum suportar uma ofensa tão vergonhosa, pois era já então de maior idade e de bom carácter, tendo reunido os seus amigos e os mais nobres de Portugal, que preferiam, de longe, ser governados por ele, do que por sua mãe ou por [pessoas] indignas e estrangeiras. Acometeu-os numa batalha no campo de S. Mamede, que é perto do castelo de Guimarães e, tendo-os vencido e esmagado, fugiram diante deles e prendeu-os. [Foi então que] se apoderou do principado e da monarquia do reino de Portugal.»

Em consonância com outras fontes, este texto coloca também a batalha de São Mamede como o primeiro episódio da história portuguesa: o começo do reino independente de Portugal. Sobre a idade de Afonso Henriques, deixa-nos apenas uma referência pouco objectiva de que ia nos dois ou três anos quando o pai morreu, mas coerente com a

\footnotetext{
${ }^{116}$ Ibid., p. 64.
} 
imprecisão subjacente aos «cerca de 14 anos de idade» da notícia precedente que, lembramos, foi escrita pela mesma mão. Sendo assim, não me parece que esta notícia traga algum esclarecimento adicional sobre o ano de nascimento de Afonso Henriques, reflectindo antes a dificuldade do autor relativamente ao ano e mês em que morreu o conde D. Henrique. Merece a pena referir que Alexandre Herculano tomou a primeira notícia da investidura como cavaleiro em 1125, com catorze anos feitos, conciliando-a com a segunda notícia de que tinha dois para três anos quando o pai morreu. Como Herculano admitiu a morte do conde D. Henrique em 1114, apontou o nascimento em $1111^{117}$. Mas, como se veio a considerar que o conde D. Henrique já se encontrava falecido dois anos antes, em 22 de Maio de $1112^{118}$, creio que foi isso que levou também a deduzir dois anos à data de nascimento proposta por Herculano, fixando-a actualmente em 1109. Contudo, o ano que melhor concilia as duas notícias é o de 1110, o mesmo proposto no De expugnatione Scallabis, escrito pela mesma altura. Não é impossível que a tradição do nascimento do nosso primeiro rei em 1109 resulte do mesmo equívoco que levou a atribuir a morte de S. Teotónio a uma sexta-feira.

Um segundo aspecto a considerar é a referência ao facto de Afonso Henriques já ser de maior idade em 1128. Se é certo que actualmente se considera a maioridade aos 18 anos, podemos incorrer num anacronismo, pois não possuímos informação sobre o mesmo conceito na sua época. Na opinião de José Mattoso ${ }^{119}$, naquela época a maioridade era atingida, de facto, aos 14 anos, o que, a admitir-se o seu nascimento em 1106, está em consonância com a sua primeira participação na confirmação de diplomas da chancelaria da sua mãe ${ }^{120}$. Por outro lado, com 22 anos em 1128, poder-se-á pensar numa provável maior autonomia de Afonso para com os senhores nortenhos que tomaram o seu partido na revolta contra $\mathrm{D}$. Teresa.

Das vinte e seis notícias dos Anais de D. Afonso, Rei dos Portugueses, que apresentamos no quadro do Anexo I, dezoito contêm menção aos anos de reinado de D. Afonso Henriques. Até ao ano de 1158, a indicação dos anos de reinado resultava da

\footnotetext{
${ }^{117}$ A. Herculano, 1989, t. 1, Notas de fim de Volume, pp. 640-641. De acordo com o fac-simile do cartaz das Festas Gualterianas de Guimarães, realizadas em 1911, apresentado por B. Fonte (2009, p. 92), foi com a data proposta por Herculano que se comemoraram os 800 anos do nascimento em 1911.

${ }^{118}$ DMP-DR, vol. 1, tomo 1, p. 45, doc. 34, de 22 de Maio de 1112, "post morte de ille comes Henricus." e tomo 2, pp. 576-577, nota XI.

${ }_{119}$ J. Mattoso, 2007, pp. 55-56.

120 DMP-DR, vol. 1, tomo 1, pp. 66-67, doc. 53, de 18 de Abril de 1120: carta de doação e couto do Porto a favor do bispo D. Hugo e seus sucessores.
} 
diferença aritmética da data da notícia relativamente ao ano de 1128, portanto não incluindo o extremo inferior. Mas, havendo nos Anais duas entradas relativas ao ano de 1158, verificamos que a primeira respeita o critério seguido anteriormente, registando 30 anos de reinado. A segunda entrada, da mesma data, regista 33 anos de reinado, o que revela falta de coerência interna dos Anais, provocada, certamente, por mão inepta do copista. Segue-se uma notícia do ano de 1162, onde se registam 35 anos de reinado, contando-se o extremo inferior, ou seja, mais um ano do que se obteria pela aplicação da regra uniformemente seguida nos anos anteriores e que não seria mais retomada. A forma de contar os 35 anos de reino na notícia dos Anais de 1162 é assim igual à da contagem da Vita Theotonii, no ano da morte do santo, ocorrida nesse mesmo ano. Ambas as contagens partem de 1128, contando o extremo inferior. Assim, no que respeita à contagem dos anos de reinado de Afonso Henriques, podemos admitir uma possível relação de dependência entre a Vita Theotonii e os Anais de Afonso I, escritos em data posterior.

Por outro lado, embora não tenhamos considerado anteriormente a autoria comum da Vita Theotonii e do De expugnatione Scallabis, a proximidade entre a produção deste último texto e os Anais de Afonso Henriques, ambos de cerca de 1185, levam-nos, a considerar agora a possibilidade de autoria comum para estes textos, que também foi avançada pelo Prof. Lindley Cintra $^{121}$ :

«Há, além disso, um passo do relato da conquista [de Santarém] que está em evidente relação com outro texto - os Anais de Afonso Henriques que constituem a última parte da Chronica Gothorum - redigido com toda a certeza em Santa Cruz (v. P. David, Études, pg. 284): a frase do De expugnatione Scalabis, «Capta est idus martii illuscescente die sabbati in era M. ${ }^{\text {a }}$ centésima $\mathrm{LXXX}^{\mathrm{a}}{ }^{\mathrm{V}}{ }^{\mathrm{a}}$ quo anno mauri, qui arabice mozamida uocantur ingressi yspaniam destruxerunt yspalim ciuitatem, me tunc agente tricesimum firme ac septimum etatis annum et regni $\mathrm{X}^{\mathrm{m}}$ VIIII. ${ }^{\mathrm{m}}$ anno nondum euoluto quo duxeram uxorem mahaldam nomine comitis amedeu filiam ex qua primogenitus est natus henricus filius meus III. ${ }^{\circ}$ nonas eiusdem mensis quo ciuitas capta est ...», está principalmente baseada nas notícias correspondentes às eras de MCLXXXIII e

\footnotetext{
${ }^{121}$ L. Cintra, 1951, vol.1, pp. CCCXCII-CCCXCIV, No 214.
} 
MCLXXXV da Chronica Gothorum. Sob a segunda destas eras lê-se por exemplo: «Idem Rex Portugalis D. Alfonsus decimo nono anno regni sui nimia audacia et animositate succinctus noctu inuasit castellum de Sanctarem ... Hoc autem factum est per uoluntarem Dei quinto Idus Maii, ad galli cantum, illuscesente die Sabbati» (PMH, Script., I, pg. 15 a, ou Fontes medievais, pgs. $38-40) . »$

Prossegue o Prof. Lindley Cintra na defesa da possibilidade da autoria comum dos Anais de Afonso Henriques, do relato da tomada de Santarém e da Vida de S. Teotónio. Tendo nós afastado a possibilidade de incluir este último texto numa autoria comum (apesar de todas as dependências anteriormente apontadas) verificamos que os exemplos que se seguem abordam sobretudo os Anais e a Tomada de Santarém:

«Não é, aliás, impossível que também estes Anais de Afonso Henriques sejam obra do autor, que suponho comum, do relato da tomada de Santarém e da Vida de S. Teotónio. Para a comunidade de autoria me inclina o estilo de certos passos dos Anais - aqueles em que se exalta a personalidade de Afonso Henriques (por exemplo, PMH, Script., I pg. 11 a, sub era MCLXIII, ou pg. 12 a, sub eris MCLXXIII e MCLXXVII) e em que aparecem comparações bíblicas («Induit uero se loricam sicut Gygas»,pg. 11 a) e, neste caso, também clássicas («quia uidebant quidem alterum Scipionem Africanum qui eos opprimeret, et affligeret. et redigeret uelut palleam in tritura aree», «mulieres ibi affuerunt Amazonico ritu belligerantes», pg. 13 a) do mesmo tipo das que se encontram nos outros textos em questão - e, principalmente, a mesma atitude de admiração sem reservas perante o Rei e o aparecimento insistente da interpretação providencialista da história que caracteriza o De expugnatione (por exemplo, na própria notícia da tomada de Santarém e na, imediatamente seguinte, da tomada de Lisboa: "... fretus Dei auxilio ...», «Hoc autem factum est per voluntatem Dei ...», "... cui prouidente ex alto diuina clementia multitudo nauium ... ex insperato aduenit in auxilium», «cepit ciuitatem ... cooperante Domini pietate et adiuuante Domine Jesu Christo». Note-se que não é sobre o providencialismo em si próprio, corrente entre os historiadores religiosos da 
época, que chamo a atenção, mas sim sobre a sua insistente aplicação a factos concretos e, por conseguinte, sobre a sua frequente manifestação).»

O facto de ambos os textos seguirem a tradição do nascimento de Afonso Henriques em 1110 (em concordância com a «feria VI» da Vita Theotonii, conforme já observamos), favorece a proposta do Prof. Lindley Cintra.

\subsubsection{Anais Lamecenses e Livro de Noa I}

As notícias dos Anais Lamecenses (Chronicon Lamecense) e da primeira parte do Livro de Noa ou Livro das Eras (ou ainda Chronicon Conimbricense) relativamente ao nascimento de D. Afonso Henriques são as seguintes:

«In Portugalia natus fuit Rex Alfonsus filius regine Tarasie et comitis Enrichi. Era (M. ${ }^{\mathrm{a}}$ C. $\left.{ }^{\mathrm{a}}\right) \mathrm{XXXX.VIII.}{ }^{\mathrm{a}} \gg(\mathrm{PMH}$, Chronicon Lamecense, SS. 19);

«Era M.C. ${ }^{\text {a }}$ XL. ${ }^{\text {a }}$ VII. ${ }^{\text {a }}$ Natus est rex alfonsus filius regine Tarasie et comitis anriqui.» (PMH, Chronicon Conimbricense, SS. 2).

Segundo a descrição de Alexandre Herculano ${ }^{122}$ :

«A Crónica Lamecense acha-se escrita em letra francesa na primeira folha de um martirológio da Sé de Lamego, e aí se diz que foi tirado autenticamente de outro mais antigo no ano de 1262; Viterbo propõe o original anterior um século. A palavra Oric ${ }^{123}$, escrita de um modo que parece mais árabe, a singeleza verdadeiramente de cronicon com que está escrito e o terminar em 1169 dão a esta opinião do autor do Elucidário tal grau de probabilidade que toca as raias da certeza.»

Por sua vez, Pierre David, através de um trabalho de crítica textual, concluiu que os Anais ditos de Lamego não constituem um testemunho distinto da recolha de Santa

\footnotetext{
${ }^{122}$ A. Herculano, 1989, t. 1, notas de fim de volume, p. 655.

${ }^{123}$ Referência ao lugar da Batalha de Ourique.
} 
Cruz $^{124}$ e que eles, juntamente com o Livro de Noa I, são testemunhos de uma primeira continuação até 1168 , dos Annales Portucalenses Veteres, perdidos ${ }^{125}$. No Livro de Noa figura a notícia do nascimento de Afonso Henriques em 1109, enquanto os Anais de Lamego apresentam o nascimento um ano mais tarde. Segundo Pierre David, a notícia da data de nascimento de D. Afonso Henriques terá sido um aditamento posterior aos aos Annales Portucalensis veteres de 1168 (perdidos), mas anterior ao «Recueil de $1189 »$ do Livro de Noa $\mathrm{I}^{126}$. Dessa data derivaram os testemunhos dos Anais de D. Afonso, do Livro de Noa e dos Anais Lamecenses. Este aspecto é importante pois a divergência na data de nascimento tanto pode resultar de erro do lado do «Recueil de 1189» como do Chronicon Lamecense, dado não haver uma relação de dependência directa entre os dois. Neste contexto, ganha nova relevância um argumento utilizado por Gonzaga de Azevedo favorável à data lamecense ${ }^{127}$ : «porque parece mais fácil cometer na cópia erro por omissão, do que por acrescentamento, convertendo a era de MCXLVIII em MCXLVII». É assim possível que ambos tenham obtido a informação do ano do nascimento de Afonso Henriques em 1110, calculado a partir da tradição parcialmente representada pela Vita Theotonii, assinalada pela anomalia «feria VI», e que tenha havido um lapso de uma unidade, no registo do ano, pelo autor do «Recueil de $1189 »$.

\section{Conclusão: Uma única fonte para todas as contradições}

A primeira referência à data de nascimento de D. Afonso Henriques encontra-se na Vita Theotonii [VT]. Esta, porém, deixa transparecer uma anomalia de cálculo de que a atribuição da morte do santo a uma sexta-feira é indício, pois os restantes elementos cronológicos da mesma notícia levariam a indicar um domingo. É possível que essa anomalia tivesse contaminado algum texto cronológico, eventualmente alguma notícia cujos elementos levariam a atribuir o nascimento de Afonso Henriques ao ano de 1110. A partir desta fonte formar-se-iam dois ramos: os que tomaram o ano da morte de São

\footnotetext{
${ }^{124}$ P. David, 1947, p. 275.

125 Ibid., p. 289.

${ }^{126}$ Ibid., p. $275-276$ e p. $306, \mathrm{n}^{\text {o }}$ 2. Para a compreensão das opções seguidas pelo editor temos de recorrer frequentemente à edição anterior na $\mathrm{PMH}$, pelo que somos levados a admitir a necessidade de se rever a transmissão textual dos Annales Portucalenses veteres e dos Annales D. Alfonsi Portugalensius regis.

${ }^{127}$ G. Azevedo, 1940, p. 241.
} 
Teotónio e os que, directa ou indirectamente, o determinaram em conformidade com a indicação do dia da semana em que o santo teria morrido (feria VI). No Anexo II apresentamos um stemma que tente representar graficamente a transmissão das várias tradições acerca do ano de nascimento de nosso primeiro rei. Do primeiro grupo fazem parte os textos da Translatio et Miracula S. Vincentii [TMSV], do Indiculum Fundationis Monasterii Beati Vincentii Vlixbone [IFMBV] e do martirológio da Sé de Lisboa [MSL]. Todos eles foram produzidos fora do scriptorum de Santa Cruz e anteriores ou com desconhecimento da notícia que se incluiu nos Anais que no mesmo mosteiro se compilaram. Tomando correctamente o ano da morte de São Teotónio em 1162, ao qual subtraíram os 56 anos do rei, obtiveram o ano do nascimento de Afonso Henriques em 1106.

Não se justifica entrar em grande detalhe relativamente a testemunhos posteriores que apenas replicam os anteriores. Refira-se apenas que esta data foi também admitida por João de Barros, Luís Gonzaga de Azevedo e Alfredo Pimenta. Neste mesmo grupo, poderíamos incluir a tradição da pia baptismal existente na Igreja de São Miguel do Castelo, em Guimarães, onde, supostamente, foi baptizado D. Afonso Henriques em 1106, de acordo com uma inscrição mandada fazer no ano de 1664 pelo prior da Colegiada de Nossa Senhora da Oliveira D. Diogo Lobo da Silveira.

No segundo grupo temos o De expugnatione Scallabis [DES], os Anais de D. Afonso Henriques [ADA], os Anais Lamecenses [AL] e o Livro de Noa I [LN I]. Todos estes textos, incluindo os Anais ditos de Lamego, teriam a sua origem no Mosteiro de Santa Cruz, onde, naturalmente, a data da morte de São Teotónio era melhor conhecida. Parece-me assim pouco verosímil que todos eles tivessem usado directamente como fonte a Vita Theotonii para calcular a data de nascimento de Afonso Henriques, a partir da referência à «feria VI», replicando o mesmo erro. Sou levado a crer que o autor desconhecido do texto do DES, procurando determinar o ano da morte de São Teotónio, que não se encontra expresso na Vita Theotonii, terá verificado que uma sexta-feira («feria VI»), 18 de Fevereiro, aconteceu no ano de 1166. Subtraindo os 56 anos de idade de Afonso Henriques referidos na Vita Theotonii, obteve a data de nascimento em 1110. Esta data não seria mais que um vestígio da referida anomalia. Representamos essa ligação no stemma por uma linha tracejada, indicadora da incerteza da hipótese textual. Ao ficar explicitada de forma directa no DES, a data de nascimento em 1110 ter-se-ia transmitido aos restantes textos produzidos no scriptorum crúzio, deixando-se de usar a 
Vita Theotonii como fonte. Desde logo aos ADA, de que podemos mesmo admitir uma autoria comum, mas também a uns hipotéticos apontamentos analísticos, acrescentados aos Annales Portucalenses veteres (perdidos) [APV], em cerca de 1185, de que o LN I e, em particular, os AL se poderão considerar testemunhos.

Fazendo também uma breve resenha desta tradição, considerada por muitos autores como a mais credível, por ser a que está espelhada nos Anais de D. Afonso, começamos por encontrar, mais tarde, o seu reflexo no Livro de Linhagens do Conde D. Pedro. O mesmo ano de 1110 veio a merecer a preferência de Frei António Brandão, no volume III da Monarquia Lusitana. São também obtidos neste ramo, tanto o nascimento de Afonso Henriques em 1111, proposto por Alexandre Herculano, como o nascimento em 1109, proposto por Torquato de Sousa Soares, Lindley Cintra e Almeida Fernandes. Refira-se ainda Bernard F. Reilly, um historiador americano que consultou praticamente toda a documentação hispânica coeva, que considera provável o nascimento em 1109 ou 1110. Ainda inserida neste ramo se encontra a inscrição do túmulo de D. Afonso Henriques existente na igreja de Santa Cruz de Coimbra que coloca o nascimento em 1110. Esta inscrição foi reelaborada em meados da década de trinta do séc. XX pelo Prof. António de Vasconcelos da Faculdade de Letras de Coimbra, a partir do epitáfio quinhentista, que apontava para 1094, baseando-se, certamente na Crónica de Duarte Galvão, cuja data basta para o eliminar como testemunho. Contudo, dois dos mais importantes estudiosos dos Anais, Monica Blöcker-Walter e Pierre David, embora citando as opiniões de outros, não tomaram posição sobre o assunto.

Pelo que ficou dito, constata-se a sobrevivência, até aos nossos dias, das duas tradições surgidas em finais do século XII. As divergências de um ano para mais ou para menos, entre as diferentes fontes associadas a cada um dos dois ramos, resultam dos problemas de transmissão textual, da complexidade e da confusão entre os diferentes métodos de cálculo de datas utilizados, num tempo em que não havia calendários. Em todo caso, não encontramos argumentos que nos levem a rejeitar a hipótese de D. Afonso Henriques ter nascido em 1106, conforme se deduz da Vita Theotonii, que elegemos neste trabalho como a primeira e melhor das fontes narrativas. Tendo morrido a 6 de Dezembro de 1185, o nosso primeiro rei terá vivido o mesmo número de anos que o santo a que ficou indelevelmente ligado: inter $\mathrm{LXX}^{\mathrm{a}}$ annos et $\mathrm{LXXX}^{\mathrm{a}}$, iusta ordinem Scripturarum.

Porto, 15 de Abril de 2010 
Anexo I: Cômputo do número de anos do reinado de D. Afonso Henriques

\begin{tabular}{|c|c|c|c|c|c|c|}
\hline \multirow{2}{*}{$\begin{array}{l}N^{0} \text { de } \\
\text { ordem }\end{array}$} & \multirow{2}{*}{ Era } & \multirow{2}{*}{$\begin{array}{l}\text { Ano } \\
\text { (1) }\end{array}$} & \multirow{2}{*}{ Notícia } & \multicolumn{3}{|c|}{$N^{o}$ anos de reinado } \\
\hline & & & & $\begin{array}{l}\text { no texto } \\
\text { (2) }\end{array}$ & \begin{tabular}{|l|} 
calculado \\
$(3)^{(a)}$
\end{tabular} & $\begin{array}{l}\text { Dif. } \\
(4)^{(b)}\end{array}$ \\
\hline 1 & MCLXIII & 1125 & Afonso Henriques armado cavaleiro & - & - & - \\
\hline 2 & MCLXVI & 1128 & Batalha de São Mamede & _- & _ & _ \\
\hline 3 & MCLXVIII & 1130 & Morte da rainha D.Teresa & 2 & 2 & 0 \\
\hline 4 & MCLXIX & 1131 & Revolta do galego Bermudo Peres & - & - & - \\
\hline 5 & MCLXX & 1132 & Edificação do Mosteiro de Santa Cruz & 4 & 4 & 0 \\
\hline 6 & MCLXXIII & 1135 & Construção do castelo de Leiria & 7 & 7 & 0 \\
\hline 7 & MCLXXV & 1137 & Infortúnio em Tomar & - & - & - \\
\hline 8 & MCLXXVII & 1139 & Batalha de Ourique & 11 & 11 & 0 \\
\hline 9 & MCLXXVIII & 1140 & Destruição do castelo de Leiria. & 12 & 12 & 0 \\
\hline 10 & MCLXXX & 1142 & Construção do castelo de Germanelo & 14 & 14 & 0 \\
\hline 11 & MCLXXXII & 1144 & Reconstrução do castelo de Leiria & 16 & 16 & 0 \\
\hline 12 & MCLXXXIII & 1145 & Casamento de Afonso Henriques & 17 & 17 & 0 \\
\hline 13 & MCLXXXV & 1147 & Conquista de Santarém & 19 & 19 & 0 \\
\hline 14 & MCXCII & 1154 & Nascimento de Sancho I & 26 & 26 & 0 \\
\hline 15 & $\mathrm{MCXCV}$ & 1157 & Morte de Afonso VII & - & - & - \\
\hline 16 & MCXCVI & 1158 & Morte da rainha Mafalda & 30 & 30 & 0 \\
\hline 17 & MCXCVI & 1158 & Conquista de Alcácer do sal & $33^{(\mathrm{c})}$ & 30 & - \\
\hline 18 & MCC & 1162 & Conquista de Beja & 35 & 34 & 1 \\
\hline 19 & MCCIV & 1166 & Conquista de Évora & - & - & - \\
\hline 20 & MCCVI & 1168 & «Desastre de Badajoz» & 41 & 40 & 1 \\
\hline 21 & MCCIX & 1171 & Nascimento do futuro rei Afonso IX & - & - & - \\
\hline 22 & MCCXII & 1174 & Sancho I casa com Dulce de Aragão & $48^{(\mathrm{c})}$ & 46 & - \\
\hline 23 & MCCXVI & 1178 & Fossado de Sancho I contra Triana & $41^{(\mathrm{c})}$ & 50 & - \\
\hline 24 & MCCXVII & 1179 & Ataque almóada ao castelo de Abrantes & 52 & 51 & 1 \\
\hline 25 & MCCXVIII & 1180 & Destruição do castelo de Coruche & 53 & 52 & 1 \\
\hline 26 & MCCXXII & 1184 & Expedição dos Almóadas & - & - & - \\
\hline
\end{tabular}

(a) $(3)=(1)-1128 ;{ }^{(b)}(4)=(2)-(3) ;{ }^{(c)}$ sic!

Fonte: Annales D. Alfonsi Portugallensium regis (ed. PMH e M. Blöcker-Walter). 


\section{Anexo II: Os testemunhos da data de nascimento de Afonso Henriques}

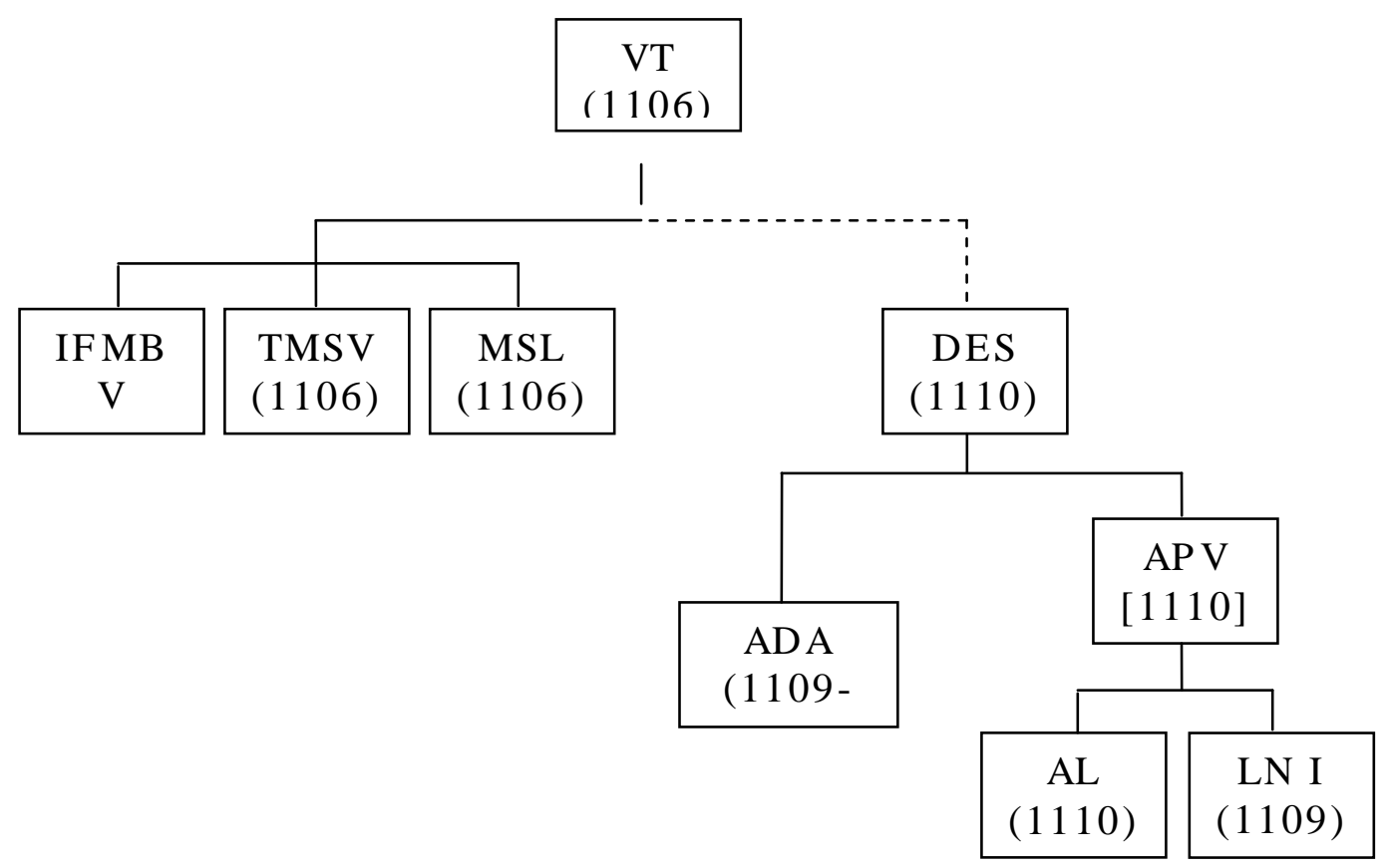

Nota: Entre parêntesis indica-se a(s) data(s) de nascimento de Afonso Henriques conforme se lê ou se deduziu das fontes.

\begin{tabular}{|l|l|l|}
\hline Sigla & Fonte & Data \\
\hline APV & Annales Portucalensis veteres (perdidos) & c. 1185 \\
ADA & Annales D. Alfonsi Portugallensium regis & c. 1185 \\
AL & Annales Lamecenses & 1262 \\
DES & De expugnatione Scallabis & c. 1184 \\
IFMBV & Indiculum Fundationis Monasterii Beati Vincentii Vlixbone & 1188 \\
LN I & Livro de Noa I & fins séc. XII \\
MSL & Martirógio da Sé de Lisboa & séc. XII-XIII ? \\
TMSV & Translatio et Miracula S. Vincentii & c. 1180 \\
VT & Vita Theotonii & c. 1162 \\
\hline
\end{tabular}

Fonte: Adaptado do stemma relativo aos diferentes Anais apresentado por J. Mattoso nas notas críticas às notas de fim de volume (in A. Herculano, 1989, XVI, p. 690-691). 


\section{Bibliografia}

Fontes

Annales D. Alfonsi Portugallensium regis - ver ed. M. Blöcker-Walter, 1966, pp. 151161.

Annales Portucalenses veteres - ver ed. P. David, 1947, pp. 291-312.

DMP-DR - Documentos Medievais Portugueses, Documentos Régios, ed. R. Azevedo, 1958-1962.

Indiculum fundationis monasterii beati Vincentii Ulixbone - ver ed. A. Nascimento, 2001, pp. 178-197.

Liber fidei: sanctae bracarensis ecclesiae - ver ed. A. Costa, 1978.

Livro Santo de Santa cruz - ver ed. L. Ventura e A. Santiago, 1990.

PMH, Portugaliae Monumenta Historica. Scriptores: Chronicon Conimbricense, Choronica Gothorum, Chronicon Lamecense.

Quomodo sit capta Sanctaren a rege alfonso comitis henrici filio - ver ed. A. Nascimento, 2005, pp. 1224-1232.

Translatio et miracula S. Vincentii - ver A. Nascimento e S. Gomes, 1988, pp. 28-91.

Vita Tellonis - ver A. Nascimento, 1998, pp. 54-121.

Vita Theotonii - ver ed. A. Nascimento, 1998, pp. 138-201.

Vita Theotonii Ms - Santa Cruz no 29 / 52, Biblioteca Pública Municipal, Porto.

Estudos

Antunes, José, 1995, A cultura erudita portuguesa nos séculos XIII e XIV (juristas e teólogos), Faculdade de Letras, Coimbra. , 1999, «Um livro sempre aberto sobre Afonso I, Rei de Portugal», in Revista de História das ideias: o livro e a leitura, Faculdade de Letras da Universidade, Coimbra.

Azevedo, Luís Gonzaga de, 1940, História de Portugal, vol. III, Lisboa, Edição «Bíblion». 
Azevedo, Rui (ed.), 1958-1962, Documentos Medievais Portugueses, Documentos Régios, 2 vol., Academia Portuguesa de História, Lisboa.

Barbosa, José, 1727, Catálogo cronológico, histórico, genealógico e crítico, das Rainhas de Portugal e seus filhos, Oficina de José António da Silva, Lisboa.

Barroca, Mário Jorge, 2000, Epigrafia Medieval Portuguesa (862-1422), Fundação Calouste Gulbenkian.

Barros, João de, 1992, Ásia, Terceira década, liv. I, cap. 4, fo. 12v, Imprensa NacionalCasa da Moeda, facsimile da edição de 1563, Lisboa.

Blöcker-Walter, Monica, 1966, Alfons I von Portugal. Studien zu Geschichte und Sage der Begrunders der portugiesichen Unbhangigkeiten, Zurich, Fretz und Wasmuth Verlag.

Bollandus, Joannes, 1736, Acta Sanctorum Quotquot Toto Orbe Coluntur, vel A Catholicis Scriptoribus Celebrantur, Veneza.

Boléo, Manuel de Paiva, [1941], Os nomes dos dias da semana em português. Influência moura ou cristã?, Coimbra Editora.

Brandão, Fr. António, 1632, Monarquia Lusitana, 3. ${ }^{a}$ parte, 1. ${ }^{a}$ ed., 4. ${ }^{a}$ ed., fac-similada, com introd. de António da Silva Rego, Lisboa, Imprensa nacional-Casa da Moeda, 1973.

Cappelli, Adriano, 1998, Cronologia, Cronografia e Calendário Perpetuo, Manuali Hoepli, Milano, 1988.

CCL, 1997, Catálogo dos Códices da Livraria de Mão do Mosteiro de Santa Cruz de Coimbra na Biblioteca Pública Municipal, Porto, coord. de Aires Augusto Nascimento e José Francisco Meirinhos.

Cintra, Luís Filipe Lindley, 1951, «Introdução», Crónica Geral de Espanha de 1344, ed. crítica, Lisboa, Academia Portuguesa da História, I, pp. CCCXCIICCCXCIV. 1989, «A lenda de Afonso I, rei de Portugal (origens e evolução)», Revista ICALP, vols. 16 e 17, Junho-Setembro, pp. 64-78.

CMA, 1968, Crónicas e Memórias Avulsas de Santa Cruz de Coimbra, intr. de António Cruz, Porto, Biblioteca Pública Municipal, Porto.

Costa, Avelino de Jesus, (ed.), 1978, Liber fidei: sanctae bracarensis ecclesiae, vol. 2, Junta Distrital, Braga. 
1984, «D. João Peculiar co-fundador do Mosteiro de Santa Cruz de Coimbra, bispo do Porto e arcebispo de Braga», in Santa Cruz de Coimbra do século XI ao século XX - Estudos no IX centenário do nascimento de São Teotónio, 10821982, Coimbra, pp. 59-83.

1993, Normas gerais de transcrição e publicação de documentos e textos medievais e modernos, $3^{\text {a }}$ ed., Instituto de Paleografia e Diplomática, Faculdade de Letras, Coimbra.

Cruz, António, 1984, «D. Teotónio, prior de Santa Cruz. O primeiro cruzado e primeiro santo de Portugal», in Santa Cruz de Coimbra do século XI ao século XX Estudos no IX centenário do nascimento de São Teotónio, 1082-1982, Coimbra, pp. 21-57.

David, Pierre, 1947, Études Historiques sur la Galice et le Portugal du VI.e au XII.e siècle, Lisboa-Paris, Collection Portugaise, Institut Français au Portugal.

DLM, Dicionário da Literatura Medieval Galega e Portuguesa, Editorial Caminho, Lisboa 1993.

Encarnação, Joaquim, D., 1982, Vida do Admiravel Padre S. Theotonio, Imprensa da Universidade, Coimbra. Fac-simile da ed. de 1855, $1^{\text {a }}$ ed. 1764.

Fernandes, A. de Almeida, 2007, Viseu, Agosto de 1109, Nasce D. Afonso Henriques, Viseu, SACRE/Fundação Mariana Seixas, $1^{a}$ edição de 1993.

Fonte, Barroso da, 2009, Afonso Henriques: um rei polémico, Editora Cidade Berço, Guimarães.

Freire, José Geraldes, 1994, «Epitáfios Latinos (Em verso e prosa) no túmulo de D. Afonso Henriques, em Coimbra», in Classica, Boletim de pedagogia e cultura, $\mathrm{n}^{\mathrm{o}} 20$, pp. 255-264, Colóquio internacional sobre o ensino do latim, Edições Colibri, Lisboa.

, 1984, «Problemas literários da Vita Sancti Theotonii», in Santa Cruz de Coimbra do século XI ao século XX - Estudos no IX centenário do nascimento de São Teotónio, 1082-1982, Coimbra, pp. 85-117.

Fundación El Legado Andalusi, 2003, Itinerario cultural de Almorávides y Almohades: Magreb y Península Ibérica, $2^{\circ}$ edicíon.

Gama, Orlando, 2009, «A memória do espaço no espaço da memória: entre a analística e os primórdios da cronística medieval», in XXIX Encontro da associação Portuguesa de História Económica e Social, Faculdade de Letras, Porto, em 
linha, consultado em 25.03.2010, disponível em http://web.letras.up.pt/aphes29/data/5th/OrlandoGama_Texto.pdf.

Gomes, Saul António, 2007, In limine conscriptionis. Documentos, chancelaria e cultura no Mosteiro de Santa Cruz de Coimbra, Séculos XII a XIV, Palimage, Viseu.

Herculano, Alexandre, 1989, História de Portugal, pref. e notas críticas de José Mattoso, Tomo I, Lisboa, Bertrand, 1ª edição de 1980.

Krus, Luís, 2000, «Historiografia. I. Época Medieval», in Dicionário da História Religiosa de Portugal, dir. Carlos Azevedo, Circulo de Leitores.

Madahil, António Gomes da Rocha, ed., 1942, Livro das Vidas dos Bispos da Sé de Coimbra, escr. no séc. XVI pelo c. Pedro Álvares Nogueira, Publicações do Arquivo e Museu de Arte da Universidade, Coimbra.

Marques, José, 1990, A realidade da igreja no tempo de S. Teotónio, Faculdade de Letras, Universidade do Porto.

2001, «Peregrinos e peregrinações medievais do ocidente peninsular nos caminhos da Terra Santa», in Estudos em homenagem a João Francisco Marques, II, p. 101-122.

Martins, Armando Alberto, 2003, O Mosteiro de Santa Cruz de Coimbra na Idade Média, Centro de História, Lisboa.

Mártires, Timóteo, Fr., 1955-1960, Crónica de Santa Cruz, edição da Biblioteca Municipal, Coimbra.

Mattoso, José, 1980, Livro de Linhagens do Conde D. Pedro, ed. crítica, publicações do II centenário da Academia das Ciências, Lisboa.

, 1985, «A primeira tarde portuguesa», in Portugal Medieval, Novas interpretações, ed. "Imprensa Nacional-Casa da Moeda”, Lisboa.

, 2007, D. Afonso Henriques, Temas e debates, Lisboa.

2009, «Afonso Henriques e as origens do reino de Portugal», Conferência de abertura ao Colóquio D. Afonso Henriques: em torno da criação e consolidação das monarquias do ocidente Europeu, de 14 a 16 de Dezembro, Faculdade de Letras, Lisboa. 
Nascimento, Aires A., 1998, Hagiografia de Santa Cruz de Coimbra, Vida de D. Telo, Vida de D. Teotónio, Vida de Martinho de Soure, ed. crítica, Edições Colibri, Lisboa.

(ed.), 2001, A Conquista de Lisboa aos Mouros. Relato de um cruzado, Intr. de Maria João Branco, Vega, Lisboa.

, 2005, «O júbilo da vitória: celebração da tomada de Santarém aos mouros (A. D. 1147)», Actes del X Congrés Internacional de l'Associació Hispànica de Literatura Medieval, ed. Rafael Alemany, etc., Barcelona, Alacant, 2005, pp. 1217-1232.

e Gomes, Saul (eds.), 1988, S. Vicente de Lisboa e seus milagres medievais, Edições Didaskalia, Lisboa.

Oliveira, Miguel de, Pe.,1994, História Eclesiástica de Portugal, Publicações EuropaAmérica.

Pereira, Armando de Sousa, 1996, «A Conquista de Santarém na tradição historiográfica portuguesa», in $2^{\circ}$ Congresso Histórico de Guimarães, Actas do congresso, Guimarães, Câmara Municipal, vol. v, pp. 297-324.

Pimenta, Alfredo, 1948, Fontes Medievais da História de Portugal, Sá da Costa, Lisboa, $1^{\mathrm{a}}$ ed, p. 26.

Rausing, Gad, 1995, «The days of the week and Dark Age politics», Forvännen 90, Stockholm, em linha, consultado em 13.01.2010, disponível em http://fornvannen.se/pdf/1990talet/1995_229.pdf.

Reilly, Bernard f., 1988, The Kingdom of León-Castilha under King Alfonso VI, 10651109, Princeton, University. , 1998, The Kingdom of León-Castilha under King Alfonso VII, 1126-1157, University of Pennsylvania Press.

Ribeiro, João Pedro, 1810, Dissertações Cronológicas e críticas, Tomo I, Lisboa.

Santa Maria, Nicolau de, 1668, Chronica da Ordem dos Cónegos Regrantes do Patriarcha S. Agostinho, Oficina de João da Costa, Lisboa.

Saraiva, José, 1942, «A data nos documentos medievais portugueses e asturo-leoneses», in Revista Portuguesa de História, Coimbra.

Silva, Carlos Guardado, 2002, O Mosteiro de São Vicente de Fora, Edições Colibri, Lisboa. 
Soares, Torquato de Sousa, 1975, «O governo do conde Henrique da Borgonha», in Revista Portuguesa de História, vol. 14, pp. 365-397.

Sousa, António Caetano, 1735, História Genealogica da Casa Real Portugueza, Officina de Joseph Antonio da Silva, Lisboa Occidental.

Ventura, Leontina e Faria, Ana Santiago, ed., 1990, Livro Santo de Santa Cruz. Cartulário do séc. XII, Centro de História da Sociedade e da Cultura da Universidade, Coimbra.

\section{COMO CITAR ESTE ARTIGO}

\section{Referência electrónica:}

ESTEFÂNIO, Abel - “A data de nascimento de Afonso I". Medievalista [Em linha]. No8, (Julho de 2010). [Consultado dd.mm.aaaa]. Disponível em http://www2.fcsh.unl.pt/iem/medievalista/MEDIEVALISTA8lestefanio8002.html. ISSN 1646-740X.

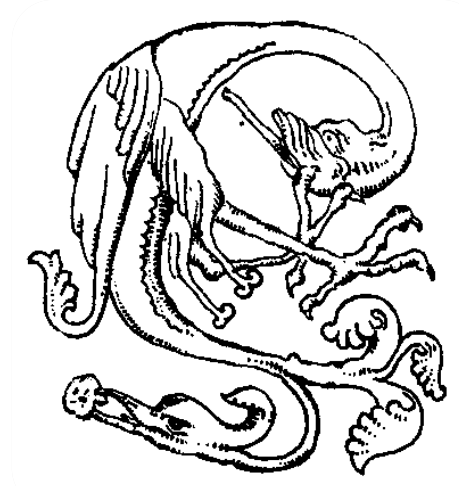

